\title{
Porous Zinc Oxide Thin Films: Synthesis Approaches and Applications
}

\author{
Marco Laurenti * and Valentina Cauda \\ Department of Applied Science and Technology, Politecnico di Torino, C.so Duca degli Abruzzi 24, \\ 10129 Turin, Italy; valentina.cauda@polito.it \\ * Correspondence: marco.laurenti@polito.it; Tel.: +39-011-090-7394
}

Received: 17 December 2017; Accepted: 7 February 2018; Published: 9 February 2018

\begin{abstract}
Zinc oxide $(\mathrm{ZnO})$ thin films have been widely investigated due to their multifunctional properties, i.e., catalytic, semiconducting and optical. They have found practical use in a wide number of application fields. However, the presence of a compact micro/nanostructure has often limited the resulting material properties. Moreover, with the advent of low-dimensional $\mathrm{ZnO}$ nanostructures featuring unique physical and chemical properties, the interest in studying $\mathrm{ZnO}$ thin films diminished more and more. Therefore, the possibility to combine at the same time the advantages of thin-film based synthesis technologies together with a high surface area and a porous structure might represent a powerful solution to prepare $\mathrm{ZnO}$ thin films with unprecedented physical and chemical characteristics that may find use in novel application fields. Within this scope, this review offers an overview on the most successful synthesis methods that are able to produce $\mathrm{ZnO}$ thin films with both framework and textural porosities. Moreover, we discuss the related applications, mainly focused on photocatalytic degradation of dyes, gas sensor fabrication and photoanodes for dye-sensitized solar cells.
\end{abstract}

Keywords: zinc oxide; thin films; high surface area; porous structure; sputtering; electrodeposition; spray pyrolysis; template-assisted methods

\section{Introduction}

Zinc Oxide ( $\mathrm{ZnO})$ is a well-known metal oxide material showing interesting biocompatible [1,2], semiconducting [3], optical [4], photocatalytic [5], resistive switching [6] and piezoelectric properties [7]. Among the main advantages, the easy preparation of $\mathrm{ZnO}$ in the form of thin films [8], nanowires [9], nanorods [10], crystalline nanoparticles [11] and flower-like structures [12] has strongly encouraged its investigation for various applications, including ultraviolet (UV) photodetectors [13], photoanodes [14], photocatalysis [5], gas sensors [15] and energy harvesting systems [16]. Historically speaking, ZnO thin films prepared by means of several synthetic approaches have been first investigated, and the resulting properties exploited for a huge number of application fields [17]. These include surface acoustic wave sensors [18], thin-film based transistors [19] and gas sensors [20]. However, ZnO thin-film based technologies suffer from some major limitations, mainly due to their intrinsic low surface area combined with the lack of a framework porosity, i.e., porosity contained within each particle composing the framework [21]. Actually, these aspects are of particular importance especially for bio- and gas-sensing applications; low surface areas prevent effective surface chemical modification treatments, limiting the sensing response and selective properties. On the other side, the absence of framework porosities prevents the possibility to host molecules of interest such as drugs and proteins, thereby limiting the use of $\mathrm{ZnO}$ thin films in biomedical applications like drug-delivery systems and tissue engineering. Some alternative solutions have been explored in view of improving at least the surface area. To this purpose, plasma-assisted chemical vapor deposition (CVD) approaches represented a valid solution for preparing low-density structure $\mathrm{ZnO}$ thin films [22]. 
Actually, plasma-CVD allowed the catalyst-free growth of $\mathrm{ZnO}$ nanocolumnar thin films with a more pronounced textural porosity, i.e., porosity due to voids and spaces formed by contacts among nanocolumns. However, no framework porosity, i.e., pores within the single $\mathrm{ZnO}$ nanocolumn, was achieved. Anyway, thanks to the higher surface area, the proposed $\mathrm{ZnO}$ nanocolumnar films were successfully applied to gas sensing [23], solar cells [24] and photocatalysis [25].

Most of the limitations mentioned above have been successfully overcome with the advent of low-dimensional $\mathrm{ZnO}$ structures. A wide plethora of synthesis methods have been explored and optimized, allowing to obtain $\mathrm{ZnO}$ structures with various shapes and morphologies, ranging from the micrometer to the nanometer scale. Among them, $\mathrm{ZnO}$ hollow-sphere particles and quantum dots are the most promising ones [26-28]. With a high surface area combined to a framework porosity, such low-dimensional $\mathrm{ZnO}$ structures exhibited improved physical properties, thanks to the presence of physical quantum confinement effects occurring in low-dimensional nanomaterials [29-31]. Despite the promising behaviors, some major concerns still prevent the integration of low-dimensional $\mathrm{ZnO}$ nanomaterials into final product applications, such as limitations in the scalability of the synthetic approaches towards large areas, as well as the reproducibility of the resulting materials properties. Therefore, the thin-film based technology still represents one of the most valid solutions in terms of industrial scalability and integration of functional materials into product applications.

Within this scope, this review aims at presenting an overview on the synthesis and applications of porous $\mathrm{ZnO}$ thin-film with well-defined textural and framework porosities. The most successful methods are found to be physical vapor depositions, especially concerning pulsed laser deposition and sputtering techniques, electrodeposition and spray pyrolysis. Other wet-chemistry approaches and template-assisted growth methods are discussed as well. In the next paragraphs, the main achievements in terms of various porous $\mathrm{ZnO}$ morphologies and corresponding application properties are discussed and correlated to each specific synthetic approach.

\section{Physical Vapor Deposition of Porous ZnO Thin Films}

Physical Vapor Deposition (PVD) methods are based on the formation of a vapor phase from a solid source material, and the following condensation on a substrate surface. Atoms and/or molecules making the vapor phase are physically extracted from the source material. This extraction process can be pursued by using various sources of energy, each one characteristic of the particular deposition method. For example, the presence of plasma is required for sputtering process, while high-energy photons coming from a laser source are exploited in the case of pulsed laser deposition (PLD). The formation process of thin films may be roughly summarized into the adsorption, nucleation and coalescence steps. The first one deals with the adsorption of atoms and/or molecules, coming from the vapor phase, on a substrate surface (adatoms). This process is driven by physisorption, i.e., weak electrostatic interactions due to Van der Waals forces, and/or chemisorption, i.e., formation of strong chemical bonds between atoms and the surface. After adsorption, nucleation and coalescence steps take place. In such situations, different adatoms start to aggregate together (nucleation), resulting in the formation of islands. These can further increase in dimensions and coalesce together, finally leading to the formation of a continuous thin film network that cover the whole substrate surface, if desired. Depending on the specific deposition parameters, each of the abovementioned steps can be properly influenced to promote the growth of island separately, avoiding the formation of a compact film. The final result would in this case lead to thin porous film, with specific micro/nanostructures and morphologies.

The following paragraphs aim at presenting an overview of the main results achieved for the growth of high surface areas and porous $\mathrm{ZnO}$ thin films by PVD methods, with a particular focus on the use of sputtering and PLD techniques.

\subsection{Sputtering}

Sputtering is a plasma-assisted PVD process where collisions between high-energy ions and the source material (target) are exploited for the formation of a vapor phase. Plasma is obtained by 
injecting a noble gas (usually argon) into the deposition chamber which is ionized by the application of a proper direct-current (DC)/radio-frequency (RF) signal voltage between a cathode, where the target is clamped, and the rest of the chamber. The impinging of ions on the target surface allows the extraction of atoms. Once the vapor phase is formed, condensation on the substrate surface takes place and thin-film formation may be pursued by the following nucleation and coalescence steps. Sputtering technology has been widely investigated because of its multiple advantages, as it is a high-yield production technology, compatible with integrated-circuit processing, and allows for the homogeneous deposition of materials on wide-area substrates. Moreover, sputtering does not necessarily require the use of high deposition temperatures. Therefore, it is compatible with the use of a wide range of substrates, including polymers.

The possibility to obtain a uniform distribution of nanopores in sputtered $\mathrm{ZnO}$ thin films was exploited for the fabrication of bio-electrodes for cholesterol detection [32]. ZnO thin films were grown on gold-coated glass substrates by RF magnetron sputtering, using a very high deposition pressure (50 mTorr). This allowed to introduce a uniform distribution of nanopores within the thin film network, as confirmed by Atomic Force Microscope (AFM) analyses. The formation of this particular structure (average rms roughness $\sim 4 \mathrm{~nm}$ ) and of the nanopores was mainly due to the high sputtering pressure used for the growth of $\mathrm{ZnO}$ thin film, since inducing a strong in-situ bombardment of the growing thin film from high-energy species. The resulting high-surface area was successfully exploited to immobilize Cholesterol Oxidase $\left(\mathrm{ChO}_{x}\right)$ enzyme onto the nanoporous $\mathrm{ZnO}$ thin-film/ $\mathrm{Au} /$ glass bio-electrodes. Both cyclic voltammetry measurements and optical studies revealed a stable and linear response of the $\mathrm{ChO}_{x} / \mathrm{ZnO} / \mathrm{Au}$ bio-electrode up to 10 weeks, coupled with a promising sensitivity (detection of cholesterol concentration in the range $25-400 \mathrm{mg} \cdot \mathrm{dL}^{-1}$ ).

Instead of using high pressure regimes during sputtering deposition, an alternative way to introduce a controlled porosity within the thin film structure is the use of a glancing-angle sputter deposition approach. By following a one-step oblique-angle deposition method, non-polar $\mathrm{ZnO}$ thin films showing a high crystal quality and porosity were successfully grown on glass substrates [33]. In this case, the sputtering gun was collimated at an oblique angle of $30^{\circ}$ with respect to the substrate surface, without any substrate rotation. Figure 1 shows the particular surface morphology featured from $\mathrm{ZnO}$ thin films obtained with this method. These were composed by highly crystalline $\mathrm{ZnO}$ microrods (approximately 1-2 $\mu \mathrm{m}$ in length and 200-600 nm in width), mainly oriented along the [002] crystallographic direction, nearly parallel to the substrate surface. At the beginning of the deposition process, the $\mathrm{ZnO}$ microrods were densely packed to each other. Then, formation of pores was observed by increasing the film thickness. This approach favored the gradual rotation of the $c$-axis growth direction, from the vertical to the nearly lateral direction with respect to the substrate, finally leading to the formation of gaps between neighbor crystal grains, and hence to the formation of pores.

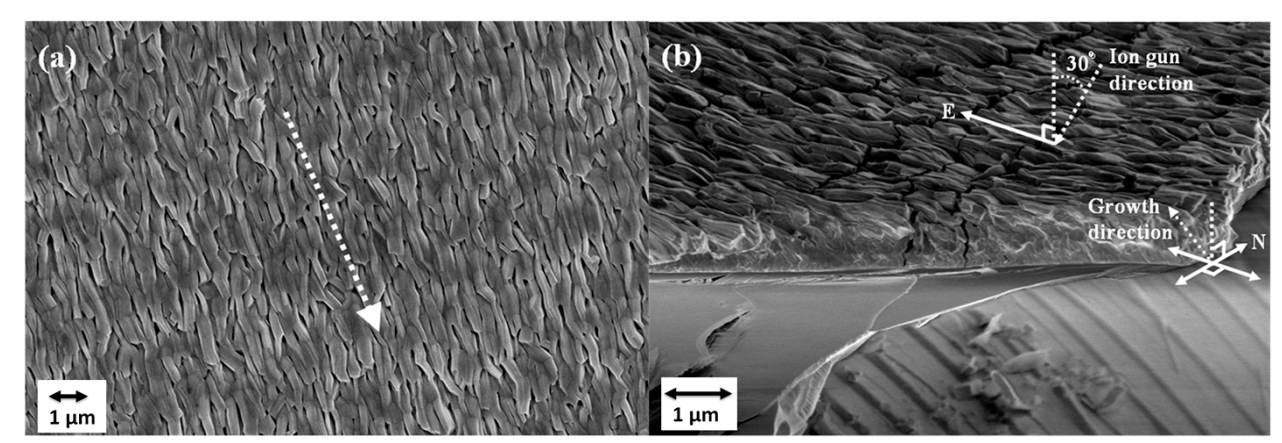

Figure 1. Scanning Electron Microscope low-magnification images: (a) Top view of as-synthesized $\mathrm{ZnO}$ film on glass substructure, where the white arrow indicates the projection of the incident flux on the film; (b) Cross-sectional view of the sample, where the ion flux and growth direction are denoted. Adapted with permission from [33]; Copyright 2013 Elsevier. 
Alternatively, the introduction of a tunable, porous microstructure within $\mathrm{ZnO}$ thin films has been observed by using unbalanced magnetron sputtering conditions [34]. To prove the effect of the magnetron configuration, the porosity of $\mathrm{ZnO}$ thin films sputtered in three different types of magnetron electrode configurations was considered, and its effect on the resulting crystal structure and UV photo-response investigated. The unbalanced conditions were obtained by progressively lowering the strength of the central magnet in the magnetron, in order to increase the ion and electron flux at the substrate. Accordingly, the plasma confinement conditions could be changed. In the case of weak central magnet conditions, a very intense bombardment effect on the substrate occurred, with the erosion of the source material occurring mainly in the center. On the other hand, minimal bombardment effects were obtained in presence of a balanced magnetron configuration. X-ray Diffraction (XRD) analyses revealed the transition from a randomly oriented, polycrystalline $\mathrm{ZnO}$ thin film with no (002) orientation for the unbalanced configuration, to a strong $c$-axis orientation along the (002) direction for the balanced case. In comparison with high (002)-oriented dense columnar $\mathrm{ZnO}$ thin films, the presence of a mixed crystallographic orientation, promoted from the unbalanced magnetron conditions, favored films transparency, the formation of smaller grain size and the arise of a porous microstructure. The porous voids, coupled to the lower kinetic energy of species sputtered in unbalanced magnetron conditions, favored oxygen trapping within the thin film structure, especially at grain boundaries. Such trapped oxygen actively participated to photo-desorption and adsorption processes occurring during UV irradiation of the sample, thereby improving UV photoresponse (rise time of $792 \mathrm{~ms}$ and fall time of $805 \mathrm{~ms}$ under low radiation intensity of $9.5 \mathrm{~mW} \cdot \mathrm{cm}^{2}$ at $\lambda_{\mathrm{UV}}=365 \mathrm{~nm}$ ). In contrast, no appreciable UV photoresponse was observed for dense $\mathrm{ZnO}$ films.

Porous $\mathrm{ZnO}$ thin films were also obtained by thermally oxidizing metallic $\mathrm{Zn}$ films deposited by DC sputtering [35]. The effect of using different pressure conditions (2 and $10 \mathrm{mTorr}$ ) and deposition atmospheres (pure Ar instead of mixed $\mathrm{Ar}+\mathrm{O}_{2}, 10 \%$ ) was first investigated. Figure 2a shows the morphology of $\mathrm{Zn}$ films grown with an Ar pressure of 2 mTorr.
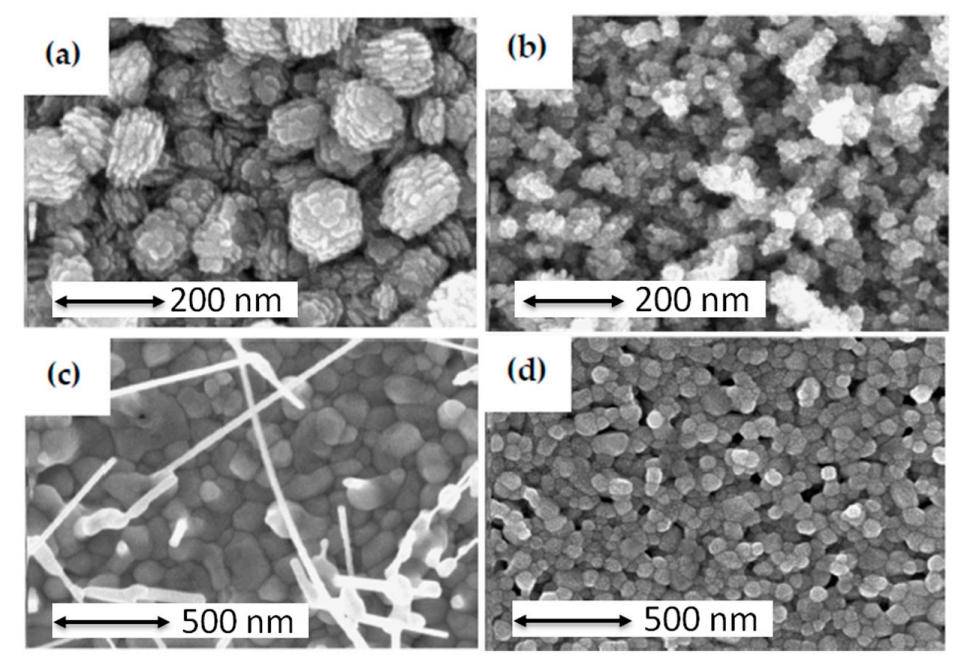

Figure 2. Surface morphologies of $\mathrm{Zn}$ films deposited on glass substrates with magnetron sputtering: (a) Ar, 2 mTorr; and (b) $\mathrm{Ar}+\mathrm{O}_{2}, 2$ mTorr. Surface morphology of $\mathrm{ZnO}$ films formed by thermal oxidation of $\mathrm{Zn}$ films at $600{ }^{\circ} \mathrm{C}$ in air for $1 \mathrm{~h}$ : (c) deposited in Ar, 10 mTorr; and (d) deposited in $\mathrm{Ar}+\mathrm{O}_{2}$, 10 mTorr. Adapted with permission from [35]; Copyright 2005 Elsevier.

The presence of hexahedron-like particles (average size of $200 \mathrm{~nm}$ ) appearing as stacks of many flat facets, was noticed. By further increasing the pressure, the particle size slightly decreased and the outer flat facets broke. By including a small oxygen percentage to the deposition atmosphere, the arise of very fine particles $(20 \mathrm{~nm})$ was observed, as shown in Figure $2 \mathrm{~b}$. These were interconnected together, forming a porous network. When the total pressure increased to $10 \mathrm{mTorr}$, the film showed many clusters 
$(\sim 150 \mathrm{~nm})$ made of fine particles $(\sim 50 \mathrm{~nm})$. The metallic $\mathrm{Zn}$ films were further oxidized in air at $600{ }^{\circ} \mathrm{C}$ for $1 \mathrm{~h}$ to be totally converted into $\mathrm{ZnO}$, as confirmed by $\mathrm{XRD}$ analyses. The morphologies of the resulting $\mathrm{ZnO}$ thin films were strongly correlated with the deposition conditions of the starting $\mathrm{Zn}$ films.

Figure 2c shows the surface morphology of $\mathrm{ZnO}$ films obtained starting from $\mathrm{Zn}$ layers grown in pure Ar conditions at 10 mTorr. Independently of the pressure value used during $\mathrm{Zn}$ deposition, a dense and compact structure was obtained after thermal oxidation, together with the presence of oxide whiskers on the surface. On the other side, the surface morphology changed after the oxidation of $\mathrm{Zn}$ films obtained from a mixed $\mathrm{Ar}+\mathrm{O}_{2}$ atmosphere. In this case, the $\mathrm{Zn}$ films grown at low pressure still showed a relatively dense structure, made of very fine particles $(\sim 40 \mathrm{~nm})$ and tower-like clusters due to some particles aggregation. However, the films deposited at a higher pressure possessed a porous structure composed of particles in the range of $60-90 \mathrm{~nm}$ after oxidation, as clearly visible in Figure $2 \mathrm{~d}$. The observed morphological changes both for $\mathrm{Zn}$ and $\mathrm{ZnO}$ thin films and the presence of a porous structure were mainly discussed in terms of deposition atmosphere conditions. The incorporation of oxygen during sputtering resulted in the formation of two phases, $\mathrm{Zn}$ and $\mathrm{ZnO}$, and into the promotion of fine particles, eventually showing a $\mathrm{Zn} / \mathrm{ZnO}$ core-shell configuration. Such structures could promote the nucleation process of oxides in the initial oxidation stage, inhibit evaporation of molten components and limit preferential growth along specific directions, thus resulting in the formation of porous films with fine particles without whisker oxides. Finally, the optical properties of the samples were investigated and correlated to the corresponding morphologies. Dense $\mathrm{ZnO}$ films coming from Zn films deposited in pure Ar exhibited low optical transmittance in visible light region, extremely strong UV emission and weak defect-related photoluminescence (PL) emissions. On the other hand, the porous multiphase $\mathrm{ZnO}$ showed a high transparency and relatively strong defect-related PL emission at room temperature.

In a similar way, porous nanobranched $\mathrm{ZnO}$ thin films with average thicknesses ranging from few $\mu \mathrm{m}$ up to tens of $\mu \mathrm{m}$, were easily fabricated by a two-step synthetic approach, involving RF magnetron sputtering of metallic $\mathrm{Zn}$ films and their oxidation by thermal annealing in ambient air a $380^{\circ} \mathrm{C}$ for $2 \mathrm{~h} \mathrm{[36]} \mathrm{or} \mathrm{alternatively,} \mathrm{by} \mathrm{low-temperature} \mathrm{water-vapor} \mathrm{oxidation} \mathrm{treatment} \mathrm{[37].} \mathrm{The} \mathrm{synthesis}$ of metallic $\mathrm{Zn}$ films was performed at room temperature in a pure Ar atmosphere, using very mild conditions in terms of applied RF signal, Ar flow and pressure. In this way, a porous metallic network with a very high surface area was obtained still from the beginning of the synthesis process (Figure 3a), and was completely preserved after the oxidation treatments mentioned above (Figure 3b,c).

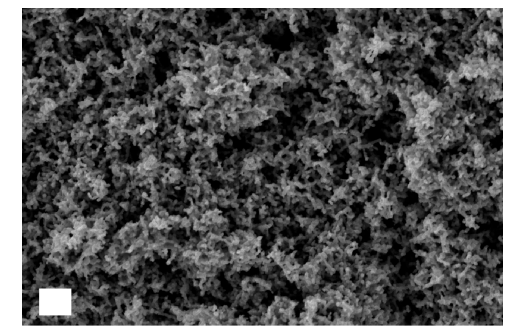

(a)

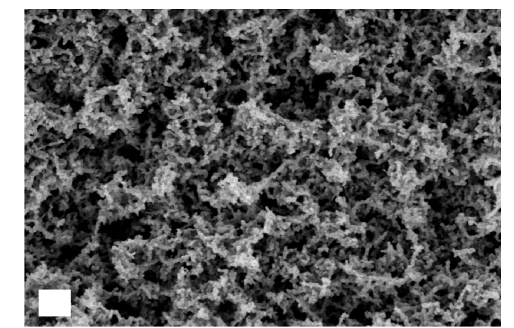

(b)

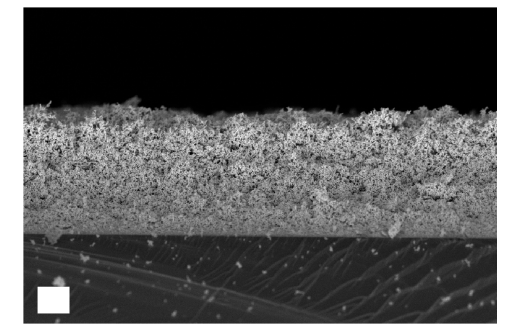

(c)

Figure 3. Field Emission Scanning Electron Microscope images of porous $\mathrm{Zn}$ thin films: (a) as-prepared; $(\mathbf{b}, \mathbf{c})$ after conversion into $\mathrm{ZnO}$ by thermal oxidation. Scale bar for (a) and (b) is $400 \mathrm{~nm}$, for (c) is $2 \mu \mathrm{m}$.

The possibility to obtain the so-called "sponge-like" porous thin-film morphology was explained through a modified "structure zone" model [36]. According to this, specific thin-film morphologies are defined considering the ratio between the substrate temperature and the melting temperature of the deposited material. Therefore, totally different morphologies can be obtained by changing the substrate temperature. On the basis of the structure zone model, the substrate temperature should lie at around $\sim 350 \mathrm{~K}$ so that the sponge-like morphology can be formed in the specific case of $\mathrm{Zn}$ thin films (melting temperature $\sim 690 \mathrm{~K})$. Such a local heating can be easily achieved during sputtering depositions and 
without providing any intentional heating to the substrates. This is due to the energy exchange occurring when high-energy particles coming from the vapor-phase collide with the substrate surface.

The developed nanobranched $\mathrm{ZnO}$ thin films were successfully exploited for a huge number of applications. By taking advantage of promising electrical and optical properties, in combination with a high specific surface area, the abovementioned porous $\mathrm{ZnO}$ layers successfully allowed optimal dye loading, resulting into efficient photoanodes for the fabrication of dye-sensitized solar cells (DSSCs) with a solar conversion efficiency up to $4.58 \%$ [38]. The porous and almost isotropic nanobranched network also promoted fast charge transport properties and a good interaction with electrolyte solutions. These factors resulted into superior performances of the porous $\mathrm{ZnO}$ matrix when tested in lithium cells for prolonged times, obtaining an almost stable specific capacity higher than $50 \mu \mathrm{A} \cdot \mathrm{h} \cdot \mathrm{cm}^{-2}$ and high Coulombic efficiencies [39]. On the other hand, photocurrent values up to four orders of magnitude higher than those measured in dark conditions underlined their promising UV sensing capability [40]. Additionally, such porous $\mathrm{ZnO}$ films showed encouraging piezoelectric properties [41], especially if compared to those obtained from $\mathrm{ZnO}$ thin films showing the more conventional dense microstructure [42]. In particular, upon external mechanical stimulation of the nanobranched $\mathrm{ZnO}$ structures, intense piezoelectric output voltage peaks and power density values were achieved, hence suggesting their promising use for sensing and energy harvesting applications $[40,42]$. The improved piezoelectric behavior was ascribed to the higher defectiveness of the porous structure with respect to the long-range ordered one, typical of dense $\mathrm{ZnO}$ thin films. This led to a general reduction in free carrier concentration and mobility, in turn limiting the screening potential and improving piezoelectric voltage generation at the same time. Lastly, the presence of a high porosity and hydrophilic behavior represented the key elements to design a novel synthetic approach for easily obtaining p-type doped nanobranched $\mathrm{ZnO}$ structures. In this case, unprecedented ferroelectric, piezoelectric and photovoltaic properties were effectively demonstrated [43].

\subsection{Pulsed Laser Deposition}

PLD is based on the ablation of a solid source upon interaction with a laser radiation. The ablated species form a vapor phase, condensate on a substrate surface and form the desired thin film after the usual nucleation and coalescence processes. One of the main advantages in using PLD is the possibility to strictly control the chemical composition of the deposited thin film, as the target stoichiometry is more effectively replied than for other PVD methods. However, particulate emission during source ablation strongly affects the performances of this deposition method.

Similar to sputtering, PLD was successfully investigated for growing highly porous ZnO thin films as well. Several works highlighted the importance in using specific oxygen background gas pressures during ablation of the material source, if a porous structure want to be pursued [44-47]. For example, dense and porous $\mathrm{ZnO}$ thin films were obtained at room temperature on silicon (Si) substrates in vacuum and in 100 mTorr $\mathrm{O}_{2}$, respectively. It was found that vacuum deposition formed a dense $\mathrm{ZnO}$ layer, while $\mathrm{O}_{2}$ atmosphere promoted the formation of a porous structure. This last also favored $\mathrm{ZnO}$ stoichiometry and the controlled formation of crystal defects like oxygen vacancies, which were almost absent for the vacuum-deposited material. By optimizing the $\mathrm{O}_{2}$ pressure (66 mTorr) and post-deposition annealing conditions, porous $\mathrm{ZnO}$ films made of $100 \mathrm{~nm}$ diameter isolated $\mathrm{ZnO}$ columns were obtained, showing good crystallinity and strong UV luminescence emission [46]. More recently, the effect of changing the $\mathrm{O}_{2}$ partial pressure on the porosity of the resulting PLD-grown $\mathrm{ZnO}$ thin films was further demonstrated [44]. In this case, Field-Emission Scanning Electron Microscopy (FESEM) and AFM analyses evidenced that small variations of oxygen pressure dramatically changed the resulting thin film morphology from porous $\mathrm{ZnO}$ crater-like nanostructures to nanoparticles. The formation process leading to the conversion of pores into nanoparticles as the oxygen pressure increased was effectively demonstrated by the corresponding reduction of surface roughness observed from AFM results. Another study about $\mathrm{ZnO}$ thin films grown by PLD discussed the formation of nanopores as a function of the deposition time [48]. 
This study evidenced how the formation, size and density of these nanopores was influenced by deposition time, due to the different interaction time between the ambient gas and the plasma plume. The growth of pores surrounded by craters was discussed on the basis of the Stranski-Krastanov growth model. All the above-mentioned results are in good agreement with previous observations of $\mathrm{ZnO}$ nanoparticles formation during PLD processes and in presence of high oxygen gas pressures. Actually, such nanoparticles allowed the following growth of high aspect ratio $\mathrm{ZnO}$ nanostructures by PLD [45]. Similarly, these nanoparticles may be considered as a sort of catalyst promoting the formation of high surface area $\mathrm{ZnO}$ thin films.

Alternatively to the use of high $\mathrm{O}_{2}$ pressure regimes, the glancing angle PLD approach, dealing with a highly oblique incident angle $\left(88^{\circ}\right)$ between rotating $\mathrm{ZnO}$ source and Si substrates, allowed the deposition of porous $\mathrm{ZnO}$ thin films as well, consisting of $100 \mathrm{~nm}$ diameter $\mathrm{ZnO}$ posts or helices [49]. The formation of such high surface area network was due to the mutual combination of self-shadowing effects between the ingrowing $\mathrm{ZnO}$ structures and substrate rotation speed. In particular, by changing the rotational speed of the substrates from 0.04 to $0.5 \mathrm{rpm}$, the morphology of the resulting $\mathrm{ZnO}$ thin films changed from few isolated helices to vertical posts having $100 \mathrm{~nm}$ in diameter. It was also hypothesized that a higher degree of porosity could be achieved by increasing the incident angle. This approach was further exploited to get porous nanostructured $\mathrm{ZnO}$ thin films applied to photoelectrochemical cells (PEC) for hydrogen generation from water splitting [50]. To find out the effect of using the oblique-angle deposition, a comparative study on the properties of $\mathrm{ZnO}$ thin films fabricated using normal PLD and oblique-angle PLD was carried out. The standard approach resulted into dense thin films with relatively large grain sizes $(200 \mathrm{~nm})$, while glancing-angle PLD returned highly porous $\mathrm{ZnO}$ structures, made of interconnected spherical nanoparticles of $15-40 \mathrm{~nm}$ in diameter. The PEC studies demonstrated that initial photocurrent and hydrogen generation efficiency were strongly influenced by the $\mathrm{ZnO}$ thin film morphology, the semiconductor-electrolyte interaction and defect density. In particular, the optimal photon-to-hydrogen efficiency $(0.6 \%)$ was obtained in the case of the porous morphology obtained by the glancing-angle approach. The improved PEC performances were ascribed to multiple effects, mainly deriving from the presence of a porous network. Firstly, the superior charge transport properties owning to diffusion phenomena taking place from nanoparticle to nanoparticle. Secondly, the decreased oxygen vacancies and $\mathrm{Zn}$ interstitials defect density compared to the dense thin film microstructure. Lastly, the large surface-to-volume ratio of the $\mathrm{ZnO}$ nanoparticle network, which guaranteed an optimal semiconductor-electrolyte interaction, enhancing the electron-hole separation properties.

The combination of effects from both oxygen-pressure and substrate temperature on the growth of $\mathrm{ZnO}$ thin films by PLD was also demonstrated. This approach was exploited to prepare high surface area, three dimensional (3D) $\mathrm{ZnO}$ nanowall networks with a nest-like structure, shown in Figure 4 [51]. The nanowall structure was obtained by a two-step PLD process. This involved first the deposition of a thin $\mathrm{ZnO}$ seed layer at a substrate temperature of $300{ }^{\circ} \mathrm{C}$ and $\mathrm{O}_{2}$ pressure of $10 \mathrm{mTorr}$. Then, the 3D nanowall $\mathrm{ZnO}$ network was obtained at $550{ }^{\circ} \mathrm{C}$ and $\mathrm{O}_{2}$ pressure of $500 \mathrm{mTorr}$. The nest-like structures were composed of a network of remarkably uniform and interconnected nanowalls, whose average thickness was around $15 \mathrm{~nm}$ (Inset A of Figure 4). AFM characterization also revealed that about $80 \%$ of the depths of the nanowall was $70 \mathrm{~nm}$ (Inset B of Figure 4). The formation of such particular 3D structure was explained in terms of a vapor-solid model. According to this, a templating/seeding effect due to self-nucleation directly occurred on the substrate surface during the beginning of the growth, at low temperature and low $\mathrm{O}_{2}$ pressure conditions. Then, formation of the 3D $\mathrm{ZnO}$ nanowall network was promoted by the following high substrate temperature and high $\mathrm{O}_{2}$ background regime.

Concerning again the effect due to different substrate temperatures and oxygen partial pressure values during PLD growth, a parametric study on the resulting morphologies, optical and structural properties was carried out [52]. Regarding the deposition time, $\mathrm{ZnO}$ nanowalls were obtained at different period of times of 5, 7, 10, 15, and $45 \mathrm{~min}$. Figure 5a shows that formation of $\mathrm{ZnO}$ nanoparticles (average size 40-390 nm) randomly distributed on the substrate surface occurred after 
$5 \mathrm{~min}$. Then, coalescence phase was observed after $7 \mathrm{~min}$ while two-dimensional $\mathrm{ZnO}$ nanowalls were grown vertically after $10 \mathrm{~min}$. In this case, the average pore size was between 50 and $140 \mathrm{~nm}$ and the walls between the honeycombs showed a uniform thickness of around $50 \mathrm{~nm}$.

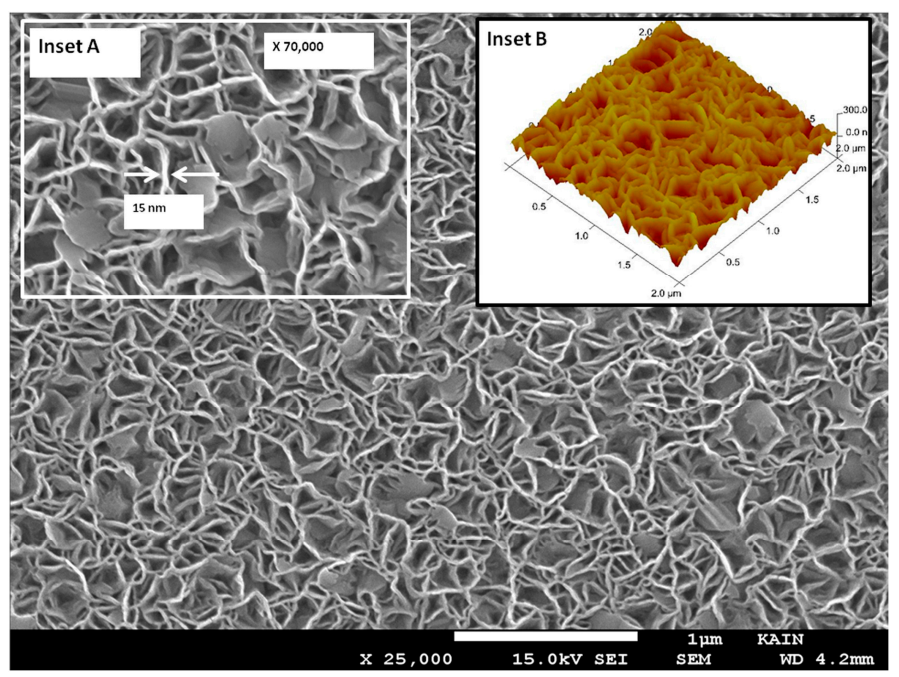

Figure 4. Low-magnification scanning electron microscope image and atomic force microscope profile of the $3 \mathrm{D} \mathrm{ZnO}$ nanowall network grown vertically on $\mathrm{Si}(100)$ at $550{ }^{\circ} \mathrm{C}$ under 0.5 Torr $\mathrm{O}_{2}$ background pressure. Scale bar is $1 \mu \mathrm{m}$. Reproduced with permission from [51]; Copyright 2015 Elsevier.

Similarly, crystalline $\mathrm{ZnO}$ thin films with a tunable porosity and anisotropic structure were prepared by changing the $\mathrm{O}_{2}$ pressure (from 100 mTorr to 400 mTorr), during PLD fabrication process [53]. The resulting films were tested as photoanodes for the fabrication of glass-based and flexible, polymer-based DSSCs. By selecting the most appropriate $\mathrm{O}_{2}$ pressure value ( $300 \mathrm{mTorr}$ ) and thickness $(10 \mu \mathrm{m})$, high surface area $\mathrm{ZnO}$ films were obtained. This allowed for an optimal dye loading, prolonged electron lifetime and enhanced electrolyte diffusion through the crystalline porous $\mathrm{ZnO}$ framework, resulting into better photovoltaic behaviors and improved conversion efficiencies (up to $3.89 \%$ ) under light illumination. Another PLD parameter affecting the porosity of $\mathrm{ZnO}$ thin films is pulse duration. This was effectively demonstrated by using a laser $\left(\lambda=810 \mathrm{~nm}\right.$, laser fluence $\left.2 \mathrm{~J} \cdot \mathrm{cm}^{-2}\right)$ with different pulse durations of $50 \mathrm{fs}, 200 \mathrm{fs}, 1 \mathrm{ps}$ and $10 \mathrm{ps}$. In such cases, porous $\mathrm{ZnO}$ films were obtained, with a degree of porosity decreasing for longer pulse durations [54].

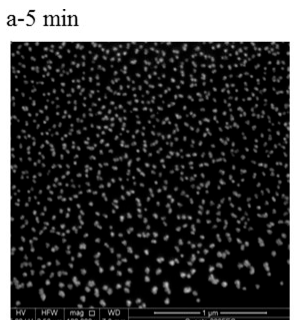

c- $10 \mathrm{~min}$

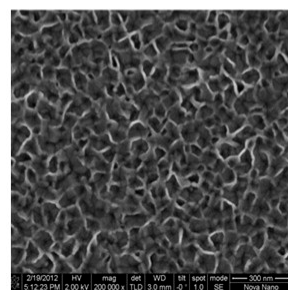

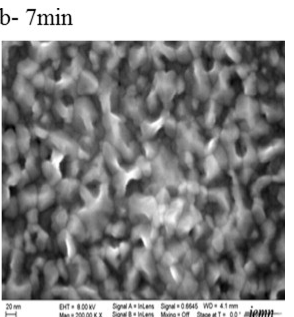

d-45 $\min$

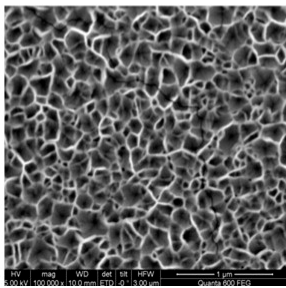

(a)

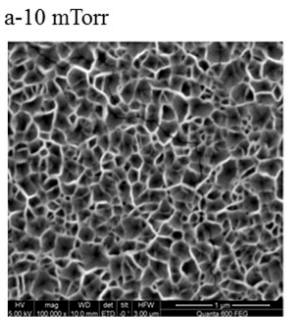

c-150 mTorr

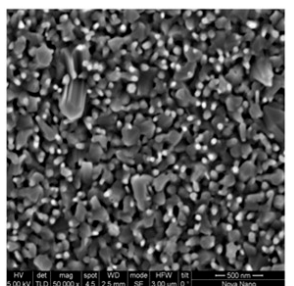

(b)

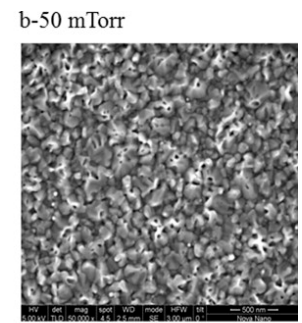

d-500 mTorr

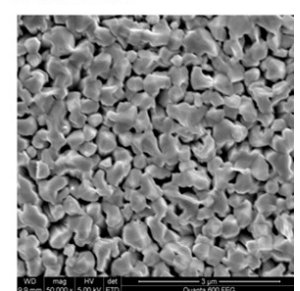

Figure 5. Cont. 

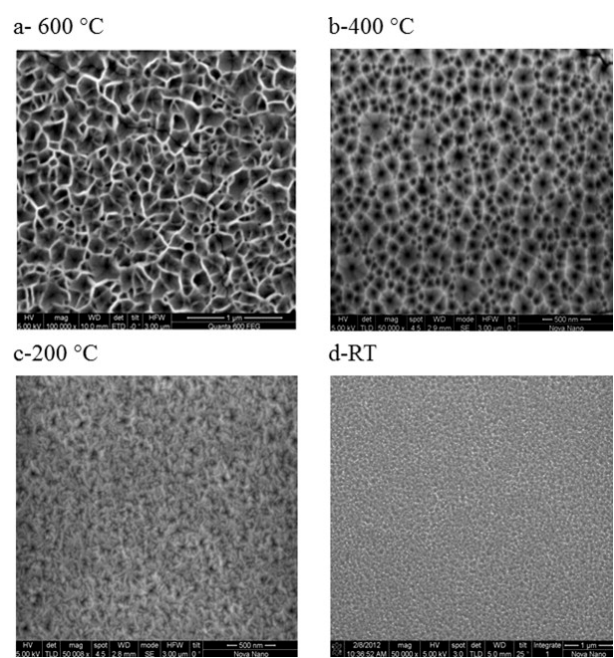

d-RT

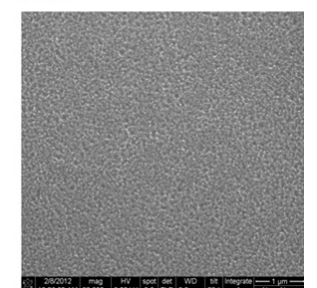

(c)

Figure 5. Scanning Electron Microscope images showing the effect of (a) deposition time, (b) oxygen pressure, and (c) substrate temperature on the morphology of the resulting ZnO nanowall network. Adapted with permission from [52]; Copyright 2014 Elsevier.

\section{Chemical Deposition of Porous ZnO Thin Films}

\subsection{Spray Pyrolysis}

Spray pyrolysis is a well-established technique used for preparing high-quality thin and thick $\mathrm{ZnO}$ films in a very simple, cheap and easy way. This synthetic approach allows for growing both dense and porous films, as well as powdered materials. The process roughly consists in three steps: atomization of a metal salt precursor solution, transportation of the resulting vapors, condensation of the drops and their thermal decomposition on a heated substrate. The formation of a thin film network is then obtained by the superimposition and overlap of the metal salt drops over the substrate surface, and their conversion into oxides by heating of the substrate. The main parameters affecting the final thin-film structure and properties are the solvent, type of salt and concentration, and additives present in the precursor solution.

Porous crystalline $\mathrm{ZnO}$ films obtained by spray pyrolysis have been reported in numerous cases. The precursor solution generally consists of zinc acetylacetonate [55], zinc nitrate [56], or zinc acetate dehydrate $[57,58]$ salts dissolved in aqueous solution. In all the cases it was found that both the use of different precursor concentrations, substrate temperatures or post-deposition thermal annealing treatments strongly influenced the resulting film morphology, photoconductive and photoluminescent properties [56-60]. The porous $\mathrm{ZnO}$ structures resulting from spray pyrolysis method generally showed good electrical conductive properties and light transparency. These aspects, coupled to optimal dye absorption properties, demonstrated their promising use as photoanodes in DSSCs fabrication [55]. Moreover, their application as blocking layer (BL) in standard $\mathrm{TiO}_{2}$-based solar cells has been successfully reported; the presence of spray-pyrolysis derived porous $\mathrm{ZnO}$ BL effectively reduced charge carrier recombination phenomena, improving the cell efficiency more than $20 \%$ with respect to cells efficiencies obtained without the BL [61]. Most of the applications based on ZnO films obtained by spray pyrolysis also rely on the fabrication of gas sensors. Several works gave evidence of their promising use as gas sensors for the detection of various gas species, including acetaldehyde [62], ammonia [63,64] and $\mathrm{H}_{2} \mathrm{~S}$ [65]. In these cases, the room temperature sensing characteristics showed that gas concentrations ranging from hundreds of ppm up to few ppm could be successfully detected with good selectivity and fast response/recovery times. In addition, other gases like methanol, ethanol, 2-propanol, benzyl alcohol and acetone were considered, further proving the best selectivity of such porous $\mathrm{ZnO}$ structures towards those abovementioned gases $[62,63,66]$. 
Another promising application of spray pyrolysis technique is the easy preparation of multifunctional doped $\mathrm{ZnO}$ films with a porous structure. In this case, doping can be achieved by simply including an additional doping precursor within the synthesis solution, such as aluminum chloride, tin chloride and silver nitrate. This approach was explored to successfully dope porous $\mathrm{ZnO}$ with various elements, including $\mathrm{Al}$ [67,68], Sn [69], Ag [70], $\mathrm{Na}$ [71], Mg [72] and many others [73,74]. Similarly to pristine $\mathrm{ZnO}$, the resulting doped structures were found to be highly promising in view of gas sensors fabrication, especially for ammonia and $\mathrm{H}_{2} \mathrm{~S}$ detection. Actually, transition metal doping $(\mathrm{Co}, \mathrm{Cu}, \mathrm{Ni})$ was proved as an effective way to achieve gas sensing properties with improved response and selectivity [75]. The $\mathrm{H}_{2} \mathrm{~S}$ sensing property and selectivity of Ti-doped $\mathrm{ZnO}$ thin films was investigated as well. The influence of Ti doping concentration on $\mathrm{H}_{2} \mathrm{~S}$ detection was considered, finding that $2 \mathrm{wt} . \%$ Ti-doped $\mathrm{ZnO}$ thin films showed the maximum response ( 0.29) to $20 \mathrm{ppm}_{2} \mathrm{~S}$ exposition at $200{ }^{\circ} \mathrm{C}$ [74]. In a similar way, $\mathrm{H}_{2} \mathrm{~S}$ sensing properties of $\mathrm{Cu}$-doped $\mathrm{ZnO}$ thin films (1-4 wt.\%) were also demonstrated [76]. In this case, the best response ( 0.38) towards $20 \mathrm{ppm} \mathrm{H}_{2} \mathrm{~S}$ at $523 \mathrm{~K}$ operating temperature was achieved for the $4 \mathrm{wt} . \% \mathrm{Cu}$-doped $\mathrm{ZnO}$. Ni-doped and $\mathrm{V}$-doped $\mathrm{ZnO}$ thin films featuring similar sensing capabilities were demonstrated too [77-79]. The acetone gas sensing tests performed on Ni-doped $\mathrm{ZnO}$ highlighted a good sensing response for acetone concentration as low as $116 \mathrm{ppb}$, with response and recovery times of about $6 \mathrm{~s}$ and $2 \mathrm{~s}$, respectively [79]. Concerning V-doped $\mathrm{ZnO}$, gas testing analyses gave evidence of good sensing response in a wide range of operating temperatures (from $350^{\circ} \mathrm{C}$ to $300^{\circ} \mathrm{C}$ ) towards $100 \mathrm{ppm}$ of acetone, $50 \mathrm{ppm}$ of ethanol and $500 \mathrm{ppm}$ of $\mathrm{H}_{2}$. Furthermore, a maximum response of 100 was achieved for acetone $100 \mathrm{ppm}$ at $450{ }^{\circ} \mathrm{C}$ [80]. Alternatively, good ammonia sensing properties were achieved for porous $\mathrm{Mg}$-doped $\mathrm{ZnO}$ thin films, with the lower Mg-doping concentration showing the best performances, with quick response and recovery times at room temperature [81].

Other successful applications for doped $\mathrm{ZnO}$ films obtained by spray pyrolysis were expressed in terms of their improved photocatalytic efficiencies and electrical properties, resulting into their successful application as photocatalyst [82,83] and as photoanodes in DSSCs fabrication [84]. Finally, In-doped and $\mathrm{Sn}$-doped $\mathrm{ZnO}$ thin films also showed very interesting antibacterial properties against Staphylococcus aureus $[85,86]$, with better antibacterial activities found by increasing the doping concentration.

\subsection{Electrodeposition}

Electrochemical deposition, also called electrodeposition, is a versatile, low cost, easy and scalable method, particularly useful for growing highly porous $\mathrm{ZnO}$ thin films at relatively low working temperatures (generally lower than $100^{\circ} \mathrm{C}$ ). This method deals with the use of charged reactive species diffusing through a solution, under the application of an external electric field. Electrodeposition is carried out in a three-electrode electrochemical cell, composed by a reference electrode $(\mathrm{Ag} / \mathrm{AgCl})$, the counter electrode (platinum wire or sheet), the working electrode and the electrolyte solution. The application of a constant voltage between the electrodes allows the diffusion of reactive species within the electrolyte solution.

Depending on several deposition parameters, like the applied voltage, deposition time, charge density and solution precursor, the porosity and morphology of electrodeposited $\mathrm{ZnO}$ films may be tuned, accordingly. For example, it has been reported that the growth rate of $\mathrm{ZnO}$ films showing different porosities and morphologies prepared by cathodic electrodeposition was influenced by sodium laurylsulfate concentration. This surfactant was added to the growth solution, made of aqueous oxygen saturated zinc chloride and other organic acids. If sodium laurylsulfate concentration was high enough, formation of micelles and their assembly on the charged electrode surface could be achieved, allowing for the formation of the porous structure, but also leading to a strong increase in the current density and finally, to the growth rate [87]. The promising optical and electrical properties of porous $\mathrm{ZnO}$ films obtained by electrodeposition have been reported in numerous cases [88-90]. In particular, it was found that enhanced photocurrent values were due to a combination of multiple effects, 
dealing with improved visible absorption properties, optimization of oxygen defects within the crystal structure, and finally the presence of an appropriate porous surface morphology, allowing for the incoming light to more effectively generate multiple reflections and diffusion scattering effects before being emitted, finally increasing the $\mathrm{ZnO}$ solar light absorption properties [89]. Such a pronounced photocurrent, coupled with a porous morphology, was successfully exploited for the fabrication of sensors and DSSCs [90]. Also in this case, the addition of surfactants during $\mathrm{ZnO}$ electrodeposition turned out to be an effective way for inducing high porosities and fast growth rates. The resulting porous samples displayed a persistent photoconductive behavior, which conductivity transients of several hours in dry atmosphere, independently of illuminating conditions. More interestingly, the photoconductive behavior was observed even when illuminating with low-bandgap energy light. This property was explained in terms of lattice relaxation processes involving surface states within the $\mathrm{ZnO}$ bandgap, which favored capture of electrons immediately after photoexcitation phenomena. Similar photoconductive properties were explored also for the fabrication of flexible photosensors [88]. In this case, fast photo-response ( $0.821 \mathrm{~s})$ and recovery times $(1.257 \mathrm{~s})$ were obtained under solar light irradiation, together with a large on/off current density ratio (65.94). Again, such promising results were mainly due to the porous $\mathrm{ZnO}$ network, able to provide more convenient photoelectron pathways and additional reaction sites for photocurrent generation.

Exploiting the promising photoelectrical properties of electrodeposited porous $\mathrm{ZnO}$ films, several works demonstrated their effective application as photoanodes in DSSCs fabrication. This was proved by Chen et al. [91], who prepared porous $\mathrm{ZnO}$ electrodes by cathodic electrodeposition from an aqueous zinc nitrate solution, also containing polyvinylpyrrolidone (PVP) as surfactant. Morphological and structural characterization showed that the porous framework was made of hexagonal wurtzite crystalline grains in the $20-40 \mathrm{~nm}$ range. Taking advantage of the film porosity and crystallinity, coupled to the optimization of the final photoanode thickness $(8 \mu \mathrm{m})$, DSSCs showing conversion efficiencies as high as 5.08\% were obtained. In another case, the promising properties of squaraine-sensitized mesoporous $\mathrm{ZnO}$ electrodes were expressed in terms of larger photocurrent generation and solar-to-energy conversion efficiencies in comparison with those obtained from standard $\mathrm{TiO}_{2}$-based electrodes sensitized with the same dye molecule [92]. Electrodeposition of nanoporous $\mathrm{ZnO}$ films were successfully deposited on conductive nanofibers as well, and tested in DSSCs [93]. Prior to deposition of the porous matrix, a compact ZnO BL was electrodeposited, in order to suppress charge carrier recombination at the interface with the conductive support. Then, during the same electrodeposition process, porous $\mathrm{ZnO}$ structures were grown by including Eosin $\mathrm{Y}$ as a pore-creating additive in the electrochemical bath.

The addition of Eosin $\mathrm{Y}$ agent to electrodeposition found use also in view of photocatalytic degradation applications. In particular, the deposition time and the Eosin concentration were optimized to get mesoporous $\mathrm{ZnO}$ thin films with large internal surface areas and good mechanical properties [94]. The photodegradation rate of methylene blue (MB) and Congo Red molecules were maximized with Eosin concentrations higher than $40 \mu \mathrm{M}$. Since the photodegradation behavior was found to be promoted in the case of the large-diameter pores, the development of narrower pores $(8 \mathrm{~nm}) \mathrm{did}$ not enhance further the $\mathrm{ZnO}$ photocatalytic performance. Another approach for the development of porous $\mathrm{ZnO}$ films with good photocatalytic properties was the electrodeposition of metallic $\mathrm{Zn}$ coatings on mild carbon steel sheet in sulfate bath by DC current, and their subsequent thermal oxidation in air at temperatures ranging between $400{ }^{\circ} \mathrm{C}$ and $800{ }^{\circ} \mathrm{C}$ [95]. In another work, the influence of annealing conditions of electrodeposited $\mathrm{Zn}$ films on the resulting photocatalytic activities were studied again in terms of MB photodegradation under UV light. The ZnO films showed good photodegradation efficiency and photostabilization, especially for the samples annealed at $500{ }^{\circ} \mathrm{C}$ for $4 \mathrm{~h}$ [96]. With this particular set of annealing conditions, uniform intertwining-rod structures were formed, showing around $100 \%$ photodegradation efficiency and good photostabilization following three successive growth reaction cycles. The observed superior properties were due to the large effective area present in the so-formed $\mathrm{ZnO}$ structures, which provided more active 
sites for radical-organic interactions and effective interfacial charge transfer, finally resulting into better photocatalytic activities. The effect of thermal oxidation at $800{ }^{\circ} \mathrm{C}$ on the morphology of electrodeposited $\mathrm{ZnO}$ films was further considered. Improved photocatalytic degradation of $\mathrm{MB}$ was obtained due to additional morphological effects deriving from the oxidation process, which led to better oxidation conditions but more strikingly, to the rise of high surface area, columnar needle or rod like $\mathrm{ZnO}$ morphologies. By controlling various deposition parameters, like the applied potential (in the range $-0.9 \sim-1.1 \mathrm{~V}$ ), the electrodeposition duration (from 1800 to $7200 \mathrm{~s}$ ) and times (from 1 to 6), a direct method was implemented to grow porous $\mathrm{ZnO}$ nanorod arrays (ZNRAs) featuring different morphologies, on stainless steel mesh substrates [97]. The photocatalytic degradation of Rhodamine- $\beta$ under UV light irradiation was investigated. The results are shown in Figure 6, highlighting how the degradation efficiency could be highly improved from $89.4 \%$ to $98.3 \%$ if deposition times increased from one to six. This was mainly due to the higher amount of $\mathrm{ZnO}$ catalyst deposited onto the steel mesh, hence resulting into higher photocatalytic efficiencies. Alternatively, electrochemical deposition allows the formation of $\mathrm{ZnO}$ nanosheets on pre-seeded substrates. Similar to porous $\mathrm{ZnO}$ thin films, the prepared nanosheet array demonstrated promising MB photodegradation properties under visible-light irradiation. In particular, the degradation efficiency could reach $90 \%$ after $180 \mathrm{~min}$, and was 1.5 times better than for commercial $\mathrm{ZnO}$ powders [98].

Due to the high specific surface area of electrodeposited $\mathrm{ZnO}$ thin films, conductive hydrophobic or even superhydrophobic surfaces were prepared as well. Superhydrophobicity could be achieved directly [99] or even by post-synthesis chemical modification treatments on the prepared $\mathrm{ZnO}$ surfaces [99,100]. In particular, Lin et al. [99] succeeded in preparing biomimetic self-cleaning ZnO surface on steel substrates, by coupling the electrodeposition of metallic Zn films on steel substrates, the consequent hydrothermal growth of low-dimensional $\mathrm{ZnO}$ structures (contact angle of $137.85^{\circ}$ ) and finally, their surface modification with low-surface-energy chemical moieties (contact angle $157.59^{\circ}$ ).

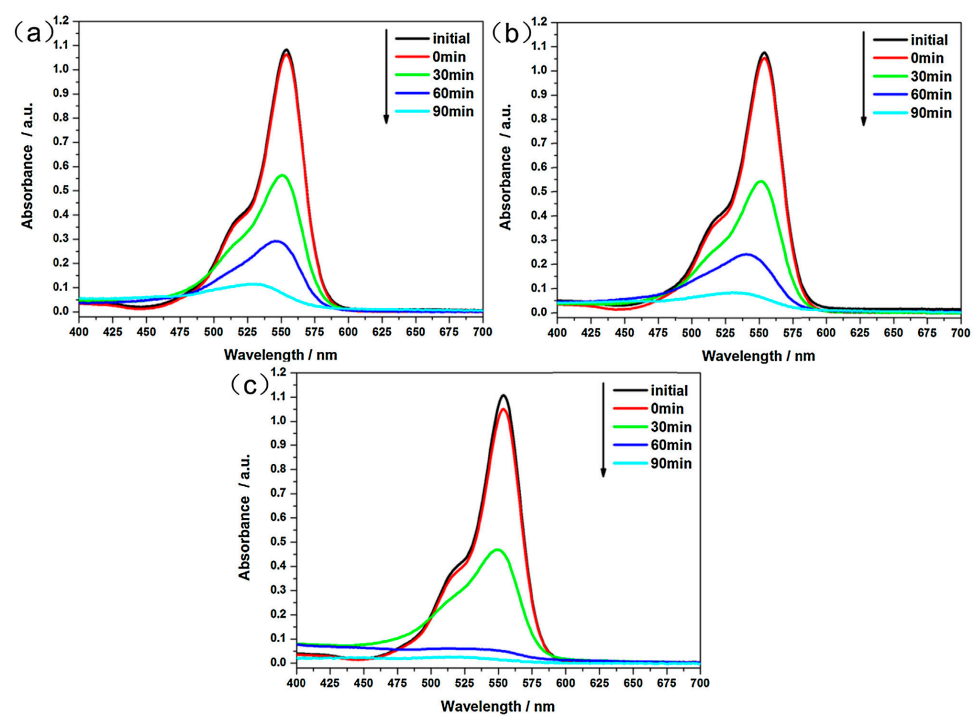

Figure 6. Absorbance spectra of Rhodamine- $\beta$ dye aqueous solutions under UV irradiation, in presence of $\mathrm{ZnO}$ nanorod arrays (ZNRAs), synthesized for different electrodeposition times: (a) one time; (b) three times; and (c) six times. Reproduced with permission from [97]; Copyright 2014 Elsevier.

\subsection{Sol-Gel Assisted Methods}

Sol-gel assisted methods have been explored as cheap and simple alternative synthetic techniques to get porous $\mathrm{ZnO}$ thin films. These include spin-coating [101], dip-coating [102], hydrothermal routes [103] and chemical bath deposition (CBD) [104-106]. The sol-gel approach first deals with the preparation of a colloidal solution combining zinc precursor powders (zinc acetate dihydrate, zinc nitrate hexahydrate or zinc chloride) and bases (sodium hydroxide), both mixed in organic 
solvents (ethanol, methanol or 2-propanol). The addition of hexamethylenetetramine to the solution is also widely recommended, since it promotes $\mathrm{ZnO}$ crystallization and allows for a strict control over the final $\mathrm{ZnO}$ morphology. The prepared solution is stirred for few hours at mild conditions $\left(60-70{ }^{\circ} \mathrm{C}\right)$ and finally deposited on the desired substrates. To further promote $\mathrm{ZnO}$ crystallization as well as the formation of the desired porous morphology, a final sintering process is generally performed for several hours at temperatures ranging between $300^{\circ} \mathrm{C}$ and $500^{\circ} \mathrm{C}$.

Sol-gel derived porous $\mathrm{ZnO}$ structures show high surface areas (see Figure 7) coupled with the existence of good optical and electrical properties. All these aspects result into interesting application properties. For example, porous $\mathrm{ZnO}$ obtained by CBD exhibited good sensing properties against a wide range of toxic and combustible gases like hydrogen, liquid petroleum gas, methane and $\mathrm{H}_{2} \mathrm{~S}$. The response of the $\mathrm{ZnO}$ thin film sensors was found to be significant, even for low gas concentrations, i.e., $50 \mathrm{ppm}$ for methane, $15 \mathrm{ppm}$ for $\mathrm{H}_{2} \mathrm{~S}$ [104]. Highly porous $\mathrm{ZnO}$ thin films prepared by a sol-gel approach showed promising photocatalytic properties, efficiently promoting the aqueous solution decomposition of phenol, chlorophenol, naphthalene and anthracene to $\mathrm{CO}_{2}$ [101]. Similar promising results were observed also for porous $\mathrm{ZnO}$ structures grown on alumina substrates. In this case, different morphologies (from nest-like to globular shape ones) were investigated and the resulting photocatalytic properties expressed in terms of Methyl Orange degradation. The highest photocatalytic activity was obtained for porous $\mathrm{ZnO}$ films sintered at $500{ }^{\circ} \mathrm{C}$ and showing successive nest-like structures [107]. The growth of highly porous $\mathrm{ZnO}$ by sol-gel approach was also applied in the pores of anodic alumina matrices having tens of $\mu \mathrm{m}$ in thickness, followed by thermal treatment $[108,109]$. Lamellar-like morphology, high surface areas (between 99 and $198 \mathrm{~m}^{2} \cdot \mathrm{g}^{-1}$ ) and pore volumes $\left(0.35\right.$ and $\left.0.1 \mathrm{~cm}^{3} \cdot \mathrm{nm}^{-1} \cdot \mathrm{g}^{-1}\right)$ were obtained for $\mathrm{ZnO}$ nanostructures into alumina. In some cases, however, the partial alumina dissolution during the synthesis process led to highly porous membrane with mixed phases of wutzitic $\mathrm{ZnO}$ and $\gamma-\mathrm{Al}_{2} \mathrm{O}_{3}$. The sol-gel method was also successfully applied to the preparation of highly porous $\mathrm{ZnO}$ films for $\mathrm{CO}$ gas sensing applications. By changing the calcination temperature, different morphologies and gas sensing responses were possible, with the best sensing response achieved for a calcination temperature of $500{ }^{\circ} \mathrm{C}[110]$. Hierarchically, 3D porous $\mathrm{ZnO}$ structures were obtained by hydrothermal method as well [103]. The analyses of both ethanol and methanol gas sensing properties demonstrated that hierarchically porous structures highly improved the gas sensing performances with respect to commercial $\mathrm{ZnO}$ powders. This was due to the high porosity and three-dimensional morphology, as making easier gas diffusion and transport within the sensing material. More recently, mesoporous $\mathrm{ZnO}$ film structures were obtained by CBD, following a green organic-solvent-free route. The high specific surface area of the prepared $\mathrm{ZnO}$ structures $\left(19-66 \mathrm{~m}^{2} \cdot \mathrm{g}^{-1}\right)$ allowed efficient drug loading and release, thereby highlighting the ability of mesoporous $\mathrm{ZnO}$ structures to work as promising drug delivery carriers [111].

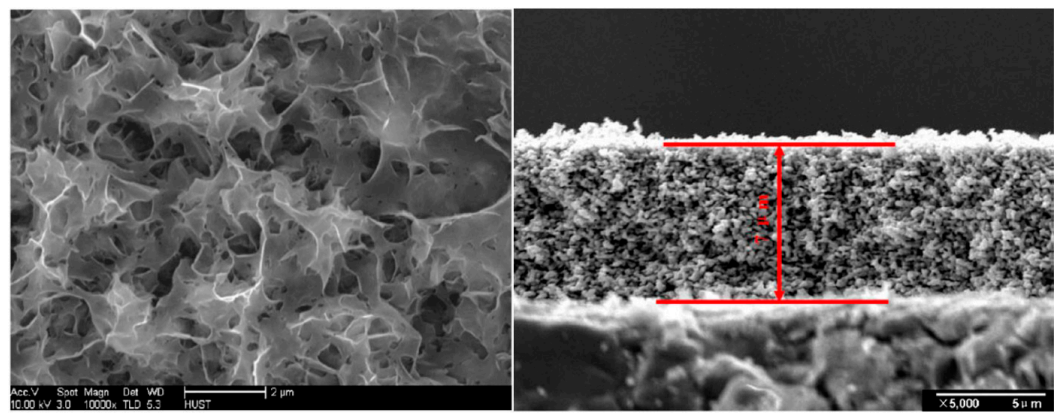

(a)

(b)

Figure 7. Examples of porous $\mathrm{ZnO}$ morphologies obtained by sol-gel methods. (a): a typical FESEM image of $\mathrm{ZnO}$ thin solid films deposited via a modified chemical bath deposition method. Scale bar is $2 \mu \mathrm{m}$. Reproduced with permission from [106]; Copyright 2006 Elsevier. (b): Cross-section FESEM image of $\mathrm{ZnO}$ films prepared at $0.05 \mathrm{~mol} / \mathrm{L}$ methanolic zinc acetate solution and sintered at $500{ }^{\circ} \mathrm{C}$. Scale bar is $5 \mu \mathrm{m}$. Reproduced with permission from [107]; Copyright 2005 Elsevier. 


\section{Template-Assisted Methods}

Porous $\mathrm{ZnO}$ thin films have been also prepared by template-assisted methods. In these cases, the macro/microporous framework is given by the use of template agents with suitable geometries. Once $\mathrm{ZnO}$ deposition on the pre-treated substrates is completed, the template is removed, leaving the desired $\mathrm{ZnO}$ porous framework.

Three-dimensional polystyrene (PS) opal [112,113] and polyethylene glycol [114] have been proposed as organic template to obtain two-dimensional or three-dimensional porous $\mathrm{ZnO}$ structures. In the first case, PS spheres were dispersed on conductive glass substrates using the vertical deposition technique, resulting in the formation of PS opal films covering the substrate surface (see Figure 8a). Then, the PS-coated substrates were used as electrode in a three-electrode cell configuration, also containing a $\mathrm{Zn}$ plate and the electrolyte solution $\left(0.04 \mathrm{M} \mathrm{Zn}\left(\mathrm{NO}_{3}\right)_{2}\right.$ in water or mixed ethanol-water solvents). The deposition process was carried out for $40 \mathrm{~min}$ or $2 \mathrm{~h}$ at $62{ }^{\circ} \mathrm{C}$ and the reference voltage was kept at $-0.96 \mathrm{~V}$ vs. reference electrode. After electrodeposition, the PS template was thermally or chemically removed, leaving the long-range ordered porous $\mathrm{ZnO}$ framework shown in Figure 8b,c. By exploiting again the combination of electrodeposition and PS templates, ordered porous $\mathrm{ZnO}$ films were obtained on conductive indium-tin-oxide glass substrates [115]. The influence of electrolyte concentration (zinc nitrate aqueous solution) on the current density, growth rate and the resulting film morphology were mostly investigated. For higher electrolyte concentrations, the deposition rate was higher, accordingly. This resulted into a better filling of the template structure, finally giving a more robust porous $\mathrm{ZnO}$ film, without showing cracks or deformation after removing the PS template. In a similar way, porous $\mathrm{ZnO}$ layers were successfully obtained on PS template glass substrates by dip coating method [116]. In this case, the influence of $\mathrm{ZnO}$ sol concentration and dipping time on the morphology of the resulting $\mathrm{ZnO}$ porous structures was pointed out, showing a shrinkage ratio of about $30 \%$ from pore to PS in the optimal synthesis conditions.
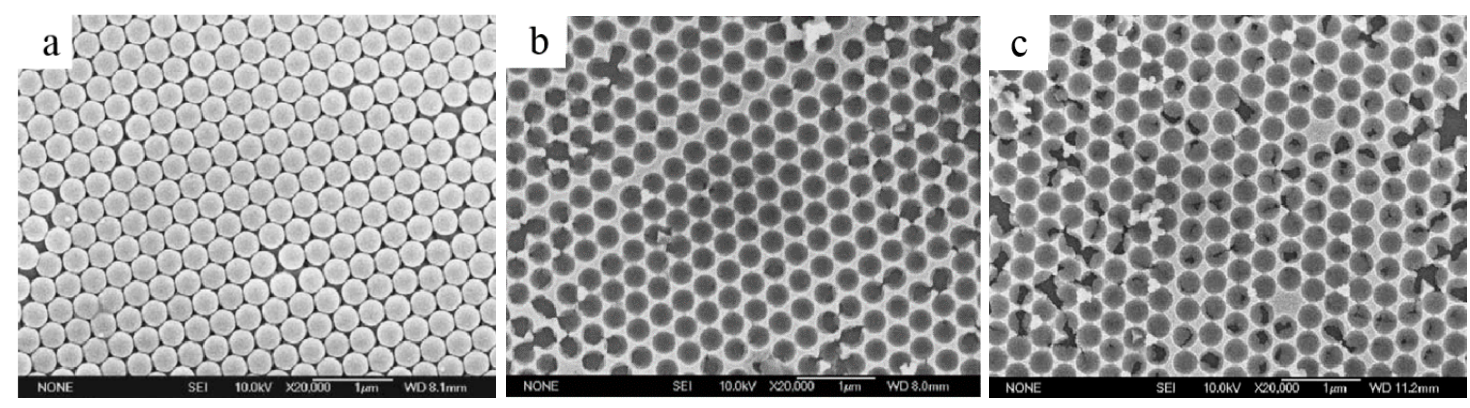

Figure 8. (a) A typical SEM image of the original PS opal templates. (b,c) SEM images of the 2D ordered $\mathrm{ZnO}$ porous films at different deposition times of (a) $40 \mathrm{~min}$ and (b) $2 \mathrm{~h}$. Adapted with permission from [113]; Copyright 2005 Elsevier.

In addition, it was highlighted how the electrostatic potential could affect the quality of the fabricated porous $\mathrm{ZnO}$ structures. For low electrodeposition potential values $(1 \mathrm{~V})$ the growth rate of $\mathrm{ZnO}$ crystals on the substrate was slow, allowing to sufficiently fill the interstices among PS spheres. This led to hemi-spherical hollow arrays after $2 \mathrm{~h}$ deposition and removal of PS template. On the contrary, at a higher potential $(1.4 \mathrm{~V})$ the crystallites grew rapidly and could not fully fill the interstices, resulting in a nanowall-like structure. Therefore, the control over the deposition potential allowed to change the pore morphology from hemispherical to a well-like structure [117]. More recently, patterned spherical nanoshells of $\mathrm{ZnO}$ were obtained for the first time [118], using an array of PS spheres prepared by self-assembly method and $80 \mathrm{~nm}$-thin $\mathrm{ZnO}$ layer deposited onto PS array by a drop-coating method. The PS array was immersed in a zinc precursor solution for several times, until the final $\mathrm{ZnO}$ thickness was achieved. Then, calcination was performed to stabilize the coating and to promote $\mathrm{ZnO}$ crystallization. Finally, PS sphere template was thermally removed, allowing the 
formation of nanoshell $\mathrm{ZnO}$ structures with clear evidence of internal voids. The UV-visible light absorption properties were highly improved due to the formation of this spherical $\mathrm{ZnO}$ nanoshell cavities. The combination of PS opal templates with $\mathrm{ZnO}$ thin films was obtained also in other cases. $\mathrm{ZnO}$ thin films deposited by RF magnetron sputtering led to the fabrication of three dimensional core-shell $\mathrm{ZnO}$ photonic crystals [119]. The PS template allowed the porous structure and formation of cavities to be properly controlled, positively affecting the resulting photonic band gap properties. Wet infiltration of PS opal templates with $\mathrm{ZnO}$ precursors also produced $\mathrm{ZnO}$ inverse-opal films with improved photodetecting properties, showing excellent selectivity and reversible response to optical switch [120]. Three-dimensionally ordered, macroporous $\mathrm{ZnO}$ structures were obtained as well [121]. Due to the high surface area $\left(18.7-34.5 \mathrm{~m}^{2} \cdot \mathrm{g}^{-1}\right)$, the macroporous structure was successfully proposed as ethanol sensor, showing good sensitivity, selectivity and electron transfer properties. In a similar preparation method, multilayered porous $\mathrm{ZnO}$ thin films were obtained and tested as $\mathrm{NO}_{2}$ gas sensor under UV light irradiation [122]. The film porosity positively influenced the ever-decaying light intensity or ever-decreasing photogenerated carriers, finally maximizing the film response when interacting with $\mathrm{NO}_{2}$ gas. Nanopatterned $\mathrm{ZnO}$ cavity-like structures were obtained as well, by the combination of hydrothermal synthesis of $\mathrm{ZnO}$ together with the use of PS opal template and nanosphere lithography technique [123]. p-n heterojunctions were then fabricated using copper oxide as p-layer, and the corresponding photoelectric conversion efficiencies evaluated. In comparison to the use of planar $\mathrm{ZnO}$ layers, the presence of a high-surface area $\mathrm{ZnO}$ cavity-like structure effectively improved the charge carrier collection within the heterojunction.

Atomic Layer Deposition (ALD) is well known for its ability to coat complex 3D substrate geometries in a conformal way. This peculiarity, in combination with the use of PS template substrates, was recently proved as an effective way to get micrometer-thick 3D mesoporous $\mathrm{ZnO}$ networks, showing a periodic gyroid structure or a random worm-like morphology as well. The presence of a mesoporous structure, with an average pore size of $30 \mathrm{~nm}$, was confirmed for both the geometries, which are shown in Figures 9 and 10. Such mesoporosity was found to be the ideal condition for promoting exciton dissociation in hybrid photovoltaic devices. This was successfully demonstrated in the case of the worm-like morphology, which was integrated into a hybrid P3HT/ZnO hybrid photovoltaic device. The presence of the mesoporous 3D worm-like $\mathrm{ZnO}$ structure effectively resulted in improved short-circuit current density values [124].

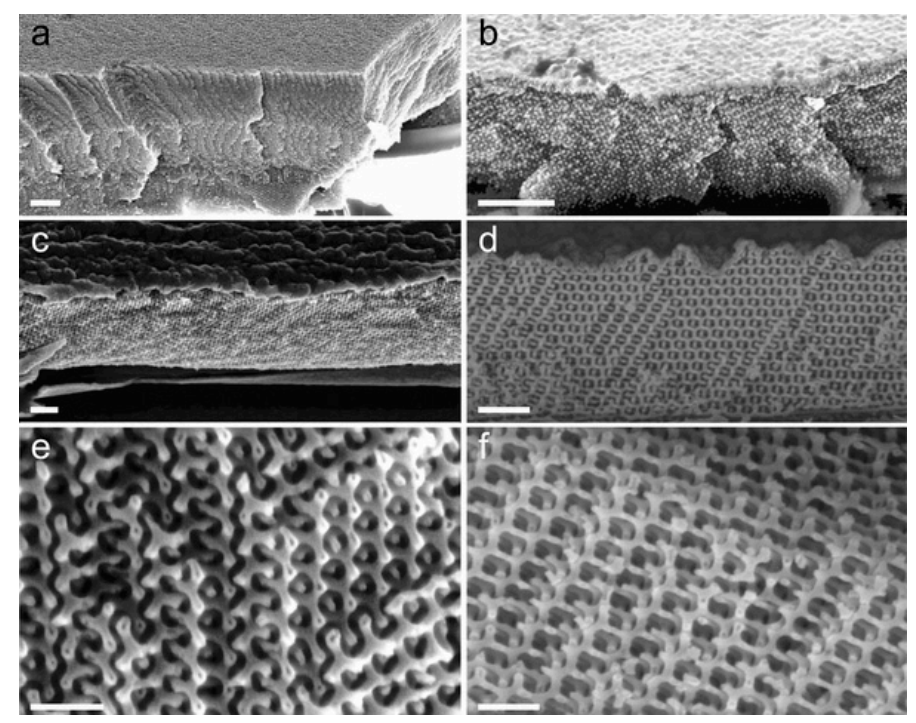

Figure 9. Side-view SEM images at a $45^{\circ}$ angle of gyroid replication into $\mathrm{ZnO}$ : (a) gyroid PS template; (b) as-deposited $\mathrm{ZnO}-\mathrm{PS}$ hybrid; (c) $\mathrm{ZnO}$ gyroid after annealing at $550{ }^{\circ} \mathrm{C}$; (d-f) different faces of the $\mathrm{ZnO}$ gyroid shown in (c). Scale bars are $1 \mu \mathrm{m}$ for panels $(\mathbf{a}, \mathbf{b}), 400 \mathrm{~nm}$ for $(\mathbf{c}, \mathbf{d}), 200 \mathrm{~nm}$ for $(\mathbf{e}, \mathbf{f})$. Reproduced with permission from [124]; Copyright 2014 John Wiley \& Sons, Inc. 


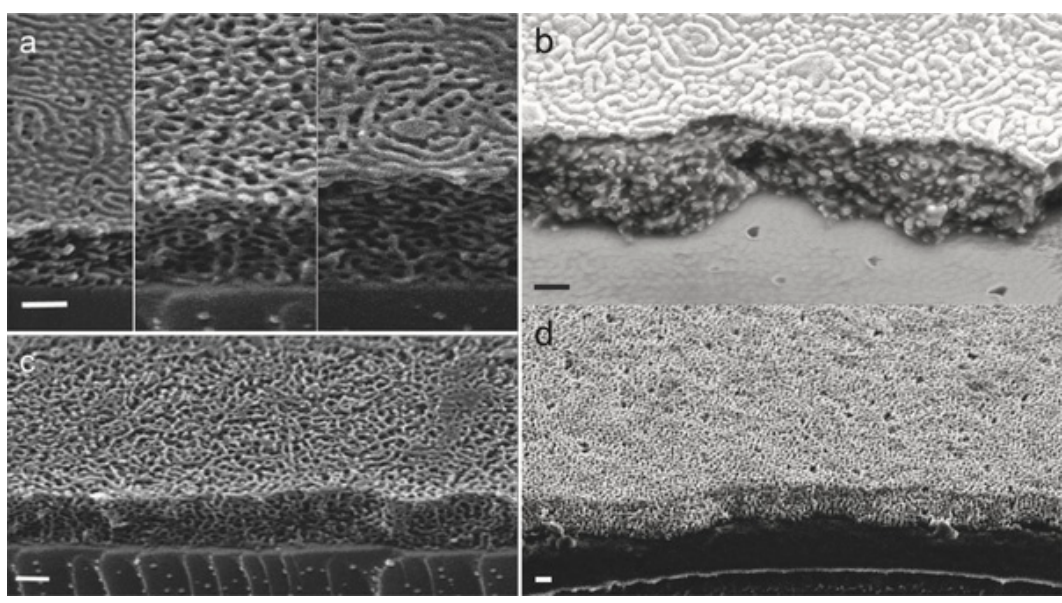

Figure 10. SEM of $\mathrm{ZnO}$ replication of the worm-like morphology: (a,c) worm-like PS template; (b) as-deposited $\mathrm{ZnO}$-PS hybrid; (d) $\mathrm{ZnO}$ morphology after annealing at $400{ }^{\circ} \mathrm{C}$ followed by etching of the top compact layer. Scale bar are $200 \mathrm{~nm}$. Reproduced with permission from [124]; Copyright 2014 John Wiley \& Sons, Inc.

\section{Others}

Apart from PVDs, chemical synthetic methods and template-assisted approaches, other works demonstrated that porous $\mathrm{ZnO}$ thin films may be easily obtained by following alternative synthetic routes/technological fabrication processes. Yong et al. exploited the oxidative action of femtosecond laser radiation to design a simple, one-step fabrication method leading to $\mathrm{ZnO}$ layer made of hierarchical micro- and nano-structures [125]. This was achieved by femtosecond laser ablation of a metallic Zn layer. The resulting laser-ablated Zn surface showed switchable wetting properties between superhydrophobic and quasi-superhydrophilic states upon UV irradiation and dark storage, respectively. The observed switchable properties were ascribed to the dual effect of the ablation process, which induced oxidation of the $\mathrm{Zn}$ surface and promoted the formation of a hierarchical rough microstructure at the same time. An alternative way to get hierarchical $\mathrm{ZnO}$ structures was achieved by a simple oxidation of metallic $\mathrm{Zn}$ films in hot water at $90{ }^{\circ} \mathrm{C}$ [126]. By changing the oxidation time, a huge amount of various morphologies could be obtained and ranging from pencil-like nanorods $(6 \mathrm{~h})$, to nanotubes $(16 \mathrm{~h})$ and lotus-like $(24 \mathrm{~h})$ structures. The occurrence of different morphologies as a function of the oxidation time was explained in terms of specific electrochemical reactions occurring at the $\mathrm{Zn}$ surface, each one predominating on the others as long as $\mathrm{ZnO}$ micro/nanostructures were going to be formed. The most interesting and promising $\mathrm{ZnO}$ structures were the lotus-like ones; when tested in hybrid organic-inorganic solar cells, a power conversion efficiency as high as $1.18 \%$ was achieved. Alcaire et al. successfully showed the fabrication of porous $\mathrm{ZnO}$ layers by the combination of vacuum- and plasma-assisted processes. In the first step, Zn-phthalocyanine (ZnPc) solid precursor was sublimated in vacuum conditions, leading to the formation of polycrystalline films rather than single crystal $\mathrm{ZnPc}$ nanowire arrays. Then, oxygen plasma treatment was used to oxidize the starting $\mathrm{ZnPc}$ film and to form the porous structure [127]. At very high substrate temperatures and/or for prolonged times, the complete conversion from $\mathrm{ZnPc}$ to $\mathrm{ZnO}$ could be achieved. In this way, highly porous $\mathrm{ZnO}$ thin films with surface coverage as low as $55 \%$ were obtained. Such a reduced density resulted into an extremely low refractive index $\left(n_{(550 \mathrm{~nm})}=1.11\right)$ for an optical thickness of $135 \mathrm{~nm}$, being one of the lowest refractive index ever reported for $\mathrm{ZnO}$. This might open the way to possible applications of such porous $\mathrm{ZnO}$ films as antireflective coatings and for graded-index multilayer systems. The anodic oxidation technique was also investigated [128]. Metallic $\mathrm{Zn}$ sheets were set as anodes in a three-electrode electrochemical cell apparatus, containing a $3 \%$ phosphoric acid in ethanol. Then, oxidation was performed by applying a constant voltage of $15 \mathrm{~V}$ for different times, ranging from $5 \mathrm{~min}$ to $2 \mathrm{~h}$. In this way, porosity of $\mathrm{ZnO}$ films was tuned accordingly. 
The cytotoxic effects of the prepared $\mathrm{ZnO}$ films were investigated, demonstrating the existence of a pore density-dependent cytotoxic behavior against fibroblast cells.

\section{Conclusions and Future Outlooks}

The main achievements in the synthesis of high-surface areas, porous $\mathrm{ZnO}$ thin films are summarized in Table 1. Various porosities of different size and cavity shapes may be successfully achieved by exploiting several deposition techniques. Sputtering and electrodeposition generally provide a mesoporous $\mathrm{ZnO}$ structure, while pulsed laser deposition, spray pyrolysis, electrodeposition and sol-gel ones often allow for different types of porosity, ranging from the meso- up to the macro-scale.

Table 1. Synthesis method, porous structure characteristics and final applications of porous zinc oxide thin films.

\begin{tabular}{|c|c|c|c|c|}
\hline \multirow{2}{*}{$\begin{array}{l}\text { Synthetic } \\
\text { Approach }\end{array}$} & \multicolumn{3}{|c|}{ Porous Structure } & \multirow[b]{2}{*}{ Ref. } \\
\hline & Type of Porosity ${ }^{1}$ & $\begin{array}{l}\text { Pore Size, Specific } \\
\text { Surface Area (SSA) }\end{array}$ & Analyses Methods & \\
\hline \multirow{4}{*}{ Sputtering } & Meso & $4 \mathrm{~nm}$ & AFM & [32] \\
\hline & Macro/Meso & $<100 \mathrm{~nm}$ & FESEM, HRTEM & [33] \\
\hline & Macro/Meso & $50-100 \mathrm{~nm}$ & FESEM & [35] \\
\hline & Meso & $\begin{array}{c}\sim 27 \mathrm{~nm}, \\
\text { SSA } 14 \mathrm{~m}^{2} \cdot \mathrm{g}^{-1}\end{array}$ & $\begin{array}{c}\text { FESEM, } \\
\mathrm{N}_{2} \text { adsorption }\end{array}$ & {$[43,129]$} \\
\hline \multirow{4}{*}{$\begin{array}{l}\text { Pulsed laser } \\
\text { deposition }\end{array}$} & Meso & $<50 \mathrm{~nm}$ & FESEM, AFM & [44] \\
\hline & Macro & $113-184 \mathrm{~nm}$ & FESEM, AFM & [48] \\
\hline & Macro & $50-140 \mathrm{~nm}$ & SEM & [52] \\
\hline & Macro/Meso & $10-100 \mathrm{~nm}$ & FESEM & [53] \\
\hline \multirow[b]{2}{*}{ Spray pyrolysis } & Macro & $\sim 100 \mathrm{~nm}$ & FESEM & [64] \\
\hline & Meso & $\begin{array}{c}10-25 \mathrm{~nm}, \\
\text { SSA } 28.88 \mathrm{~m}^{2} \cdot \mathrm{g}^{-1}\end{array}$ & $\mathrm{~N}_{2}$ adsorption & [79] \\
\hline \multirow{3}{*}{ Electro deposition } & Meso & $10-20 \mathrm{~nm}$ & FESEM & [92] \\
\hline & Meso & $<50 \mathrm{~nm}$ & SEM, TEM & [93] \\
\hline & Meso & $\begin{array}{c}<8 \mathrm{~nm}, \\
\text { SSA } 20-140 \mathrm{~m}^{2} \cdot \mathrm{g}^{-1}\end{array}$ & $\mathrm{Kr}$ adsorption & [94] \\
\hline \multirow[t]{2}{*}{ Sol-gel } & Meso & $\begin{array}{c}\sim 7 \mathrm{~nm}, \\
\text { SSA } 37.47 \mathrm{~m}^{2} \cdot \mathrm{g}^{-1}\end{array}$ & $\mathrm{~N}_{2}$ adsorption & [103] \\
\hline & Macro & $\sim 100 \mathrm{~nm}$ & FESEM & [105] \\
\hline \multirow{2}{*}{ Template-assisted } & Macro & $>1 \mu \mathrm{m}$ & FESEM & {$[112,113,116,117]$} \\
\hline & Meso & $30 \mathrm{~nm}$ & FESEM & [124] \\
\hline
\end{tabular}

Independently of the particular synthetic approach, the prepared porous $\mathrm{ZnO}$ films found successful application for the fabrication of photoanodes for DSSCs, the photocatalytic degradation of various dye molecules, and for the fabrication of gas sensors. In the specific case of spray pyrolysis, this method turned out to be the most successful and simple methods to easily synthesize doped $\mathrm{ZnO}$ thin films with a porous structure. As an alternative to the methods mentioned above, template-assisted methods successfully allowed for the growth of three dimensional porous $\mathrm{ZnO}$ structures, also showing very complex 3D geometries. In most of the cases, polystyrene opals have been definitely proved as the most promising sacrificial template useful to confer the desired macro/microporosity after $\mathrm{ZnO}$ deposition.

New future applications could be envisioned for porous $\mathrm{ZnO}$ thin films, thanks to the combination of the following aspects: (i) very interesting $\mathrm{ZnO}$ properties, i.e., antibacterial activity, piezoelectricity and biocompatibility; (ii) the existence of mesoporous/macroporous structures with high surface areas; (iii) the use of thin-film-based technologies, allowing for the preparation of large-area substrate materials in a controllable and repeatable way. Actually, the existence of mesoporous $\mathrm{ZnO}$ thin films would allow for several drugs and biologically relevant molecules to be loaded and delivered, 
hence opening the way to the application of porous $\mathrm{ZnO}$ structures for drug-delivery systems. On the other hand, macroporous $\mathrm{ZnO}$ structures showing good antibacterial and piezoelectric activities might allow for the design of new piezoelectric-active scaffold materials for tissue engineering applications.

Author Contributions: Marco Laurenti and Valentina Cauda jointly conceived the topic and outline of the manuscript; Marco Laurenti wrote the paper; Valentina Cauda supervised the overall writing of the manuscript.

Conflicts of Interest: The authors declare no conflict of interest.

\section{References}

1. Zhu, P.; Weng, Z.Y.; Li, X.; Liu, X.M.; Wu, S.L.; Yeung, K.W.K.; Wang, X.B.; Cui, Z.D.; Yang, X.J.; $\mathrm{Chu}$, P.K. Biomedical applications of functionalized $\mathrm{ZnO}$ nanomaterials: From biosensors to bioimaging. Adv. Mater. Interfaces 2016, 3, 1500494. [CrossRef]

2. Laurenti, M.; Cauda, V. ZnO nanostructures for tissue engineering applications. Nanomaterials 2017, 7, 374. [CrossRef] [PubMed]

3. Janotti, A.; Van de Walle, C.G. Fundamentals of zinc oxide as a semiconductor. Rep. Prog. Phys. 2009, 72, 126501. [CrossRef]

4. Djurisic, A.B.; Leung, Y.H. Optical properties of ZnO nanostructures. Small 2006, 2, 944-961. [CrossRef] [PubMed]

5. Yu, J.G.; Yu, X.X. Hydrothermal synthesis and photocatalytic activity of zinc oxide hollow spheres. Environ. Sci. Technol. 2008, 42, 4902-4907. [CrossRef] [PubMed]

6. Laurenti, M.; Porro, S.; Pirri, C.F.; Ricciardi, C.; Chiolerio, A. Zinc oxide thin films for memristive devices: A review. Crit. Rev. Solid State Mater. Sci. 2017, 42, 153-172. [CrossRef]

7. Wang, Z.L. Zinc oxide nanostructures: Growth, properties and applications. J. Phys. Condens. Matter 2004, 16, R829-R858. [CrossRef]

8. Laurenti, M.; Stassi, S.; Lorenzoni, M.; Fontana, M.; Canavese, G.; Cauda, V.; Pirri, C.F. Evaluation of the piezoelectric properties and voltage generation of flexible zinc oxide thin films. Nanotechnology 2015, 26, 215704. [CrossRef] [PubMed]

9. Cui, J.B. Zinc oxide nanowires. Mater. Charact. 2012, 64, 43-52. [CrossRef]

10. Li, J.Y.; Chen, X.L.; Li, H.; He, M.; Qiao, Z.Y. Fabrication of zinc oxide nanorods. J. Cryst. Growth 2001, 233, 5-7. [CrossRef]

11. Dumontel, B.; Canta, M.; Engelke, H.; Chiodoni, A.; Racca, L.; Ancona, A.; Limongi, T.; Canavese, G.; Cauda, V. Enhanced biostability and cellular uptake of zinc oxide nanocrystals shielded with a phospholipid bilayer. J. Mater. Chem. B 2017, 5, 8799-8813. [CrossRef]

12. Cauda, V.; Pugliese, D.; Garino, N.; Sacco, A.; Bianco, S.; Bella, F.; Lamberti, A.; Gerbaldi, C. Multi-functional energy conversion and storage electrodes using flower-like zinc oxide nanostructures. Energy 2014, 65, 639-646. [CrossRef]

13. Soci, C.; Zhang, A.; Xiang, B.; Dayeh, S.A.; Aplin, D.P.R.; Park, J.; Bao, X.Y.; Lo, Y.H.; Wang, D. ZnO nanowire UV photodetectors with high internal gain. Nano Lett. 2007, 7, 1003-1009. [CrossRef] [PubMed]

14. Jiang, C.Y.; Sun, X.W.; Lo, G.Q.; Kwong, D.L.; Wang, J.X. Improved dye-sensitized solar cells with a ZnOnanoflower photoanode. Appl. Phys. Lett. 2007, 90, 263501. [CrossRef]

15. Wang, C.X.; Yin, L.W.; Zhang, L.Y.; Xiang, D.; Gao, R. Metal oxide gas sensors: Sensitivity and influencing factors. Sensors 2010, 10, 2088-2106. [CrossRef] [PubMed]

16. Wang, Z.L.; Song, J.H. Piezoelectric nanogenerators based on zinc oxide nanowire arrays. Science 2006, 312, 242-246. [CrossRef] [PubMed]

17. Ozgur, U.; Alivov, Y.I.; Liu, C.; Teke, A.; Reshchikov, M.A.; Dogan, S.; Avrutin, V.; Cho, S.J.; Morkoc, H. A comprehensive review of ZnO materials and devices. J. Appl. Phys. 2005, 98, 041301. [CrossRef]

18. Fu, Y.Q.; Luo, J.K.; Du, X.Y.; Flewitt, A.J.; Li, Y.; Markx, G.H.; Walton, A.J.; Milne, W.I. Recent developments on $\mathrm{ZnO}$ films for acoustic wave based bio-sensing and microfluidic applications: A review. Sens. Actuators B Chem. 2010, 143, 606-619. [CrossRef]

19. Fortunato, E.; Barquinha, P.; Martins, R. Oxide semiconductor thin-film transistors: A review of recent advances. Adv. Mater. 2012, 24, 2945-2986. [CrossRef] [PubMed] 
20. Eranna, G.; Joshi, B.C.; Runthala, D.P.; Gupta, R.P. Oxide materials for development of integrated gas sensors-A comprehensive review. Crit. Rev. Solid State Mater. Sci. 2004, 29, 111-188. [CrossRef]

21. Tanev, P.T.; Pinnavaia, T.J. Mesoporous silica molecular sieves prepared by ionic and neutral surfactant templating: A comparison of physical properties. Chem. Mater. 1996, 8, 2068-2079. [CrossRef]

22. Romero-Gomez, P.; Toudert, J.; Sanchez-Valencia, J.R.; Borras, A.; Barranco, A.; Gonzalez-Elipe, A.R. Tunable nanostructure and photoluminescence of columnar ZnO films grown by plasma deposition. J. Phys. Chem. C 2010, 114, 20932-20940. [CrossRef]

23. Sanchez-Valencia, J.R.; Alcaire, M.; Romero-Gomez, P.; Macias-Montero, M.; Aparicio, F.J.; Borras, A.; Gonzalez-Elipe, A.R.; Barranco, A. Oxygen optical sensing in gas and liquids with nanostructured $\mathrm{ZnO}$ thin films based on exciton emission detection. J. Phys. Chem. C 2014, 118, 9852-9859. [CrossRef]

24. Ramos, F.J.; Lopez-Santos, M.C.; Guillen, E.; Nazeeruddin, M.K.; Gratzel, M.; Gonzalez-Elipe, A.R.; Ahmad, S. Perovskite solar cells based on nanocolumnar plasma-deposited $\mathrm{ZnO}$ thin films. Chemphyschem 2014, 15, 1148-1153. [CrossRef] [PubMed]

25. Simon, Q.; Barreca, D.; Gasparotto, A.; Maccato, C.; Montini, T.; Gombac, V.; Fornasiero, P.; Lebedev, O.I.; Turner, S.; Van Tendeloo, G. Vertically oriented $\mathrm{CuO} / \mathrm{ZnO}$ nanorod arrays: From plasma-assisted synthesis to photocatalytic H-2 production. J. Mater. Chem. 2012, 22, 11739-11747. [CrossRef]

26. Bakrudeen, H.B.; Tsibouklis, J.; Reddy, B.S.R. Facile fabrication of mesoporous ZnO nanospheres for the controlled delivery of captopril. J. Nanoparticle Res. 2013, 15, 1505. [CrossRef]

27. Zeng, H.B.; Cai, W.P.; Liu, P.S.; Xu, X.X.; Zhou, H.J.; Klingshirn, C.; Kalt, H. ZnO-based hollow nanoparticles by selective etching: Elimination and reconstruction of metal-semiconductor interface, improvement of blue emission and photocatalysis. ACS Nano 2008, 2, 1661-1670. [CrossRef] [PubMed]

28. Cai, X.L.; Luo, Y.N.; Zhang, W.Y.; Du, D.; Lin, Y.H. pH-sensitive ZnO quantum dots-doxorubicin nanoparticles for lung cancer targeted drug delivery. ACS Appl. Mater. Inter. 2016, 8, 22442-22450. [CrossRef] [PubMed]

29. Park, W.I.; Yi, G.C.; Kim, M.; Pennycook, S.J. Quantum confinement observed in ZnO/ZnMgO nanorod heterostructures. Adv. Mater. 2003, 15, 526-529. [CrossRef]

30. Wang, Z.L. Splendid one-dimensional nanostructures of zinc oxide: A new nanomaterial family for nanotechnology. ACS Nano 2008, 2, 1987-1992. [CrossRef] [PubMed]

31. Yin, M.; Gu, Y.; Kuskovsky, I.L.; Andelman, T.; Zhu, Y.; Neumark, G.F.; O’Brien, S. Zinc oxide quantum rods. J. Am. Chem. Soc. 2004, 126, 6206-6207. [CrossRef] [PubMed]

32. Singh, S.P.; Arya, S.K.; Pandey, P.; Malhotra, B.D.; Saha, S.; Sreenivas, K.; Gupta, V. Cholesterol biosensor based on rf sputtered zinc oxide nanoporous thin film. Appl. Phys. Lett. 2007, 91, 063901. [CrossRef]

33. Lai, Y.F.; Huang, J.H.; Chen, Y.C.; Liu, C.P.; Yang, Y.W. Growth of large-area non-polar ZnO film without constraint to substrate using oblique-angle sputtering deposition. J. Eur. Ceram. Soc. 2013, 33, 1809-1814. [CrossRef]

34. Sharma, P.; Mansingh, A.; Sreenivas, K. Ultraviolet photoresponse of porous ZnO thin films prepared by unbalanced magnetron sputtering. Appl. Phys. Lett. 2002, 80, 553-555. [CrossRef]

35. Li, L.; Gao, W.; Reeves, R.J. Zinc oxide films by thermal oxidation of zinc thin films. Surf. Coat. Technol. 2005, 198, 319-323. [CrossRef]

36. Gazia, R.; Chiodoni, A.; Bianco, S.; Lamberti, A.; Quaglio, M.; Sacco, A.; Tresso, E.; Mandracci, P.; Pirri, C.F. An easy method for the room-temperature growth of spongelike nanostructured $\mathrm{Zn}$ films as initial step for the fabrication of nanostructured ZnO. Thin Solid Films 2012, 524, 107-112. [CrossRef]

37. Lamberti, A.; Sacco, A.; Laurenti, M.; Fontana, M.; Pirri, C.F.; Bianco, S. Sponge-like ZnO nanostructures by low temperature water vapor-oxidation method as dye-sensitized solar cell photoanodes. J. Alloy Comp. 2014, 615, S487-S490. [CrossRef]

38. Lamberti, A.; Gazia, R.; Sacco, A.; Bianco, S.; Quaglio, M.; Chiodoni, A.; Tresso, E.; Pirri, C.F. Coral-shaped ZnO nanostructures for dye-sensitized solar cell photoanodes. Prog. Photovolt. 2014, 22, 189-197. [CrossRef]

39. Garino, N.; Lamberti, A.; Gazia, R.; Chiodoni, A.; Gerbaldi, C. Cycling behaviour of sponge-like nanostructured $\mathrm{ZnO}$ as thin-film Li-ion battery anodes. J. Alloy Comp. 2014, 615, S454-S458. [CrossRef]

40. Gazia, R.; Motto, P.; Stassi, S.; Sacco, A.; Virga, A.; Lamberti, A.; Canavese, G. Photodetection and piezoelectric response from hard and flexible sponge-like ZnO-based structures. Nano Energy 2013, 2, 1294-1302. [CrossRef] 
41. Gazia, R.; Canavese, G.; Chiodoni, A.; Lamberti, A.; Stassi, S.; Sacco, A.; Bianco, S.; Virga, A.; Tresso, E.; Pirri, C.F. Novel spongelike nanostructured ZnO films: Properties and applications. J. Alloy Comp. 2014, 586, S331-S335. [CrossRef]

42. Laurenti, M.; Canavese, G.; Stassi, S.; Fontana, M.; Castellino, M.; Pirri, C.F.; Cauda, V. A porous nanobranched structure: An effective way to improve piezoelectricity in sputtered $\mathrm{ZnO}$ thin films. RSC Adv. 2016, 6, 76996. [CrossRef]

43. Laurenti, M.; Canavese, G.; Sacco, A.; Fontana, M.; Bejtka, K.; Castellino, M.; Pirri, C.F.; Cauda, V. Nanobranched $\mathrm{ZnO}$ structure: p-type doping induces piezoelectric voltage generation and ferroelectricphotovoltaic effect. Adv. Mater. 2015, 27, 4218-4223. [CrossRef] [PubMed]

44. Ghosh, P.; Sharma, A.K. Highly c-axis oriented growth and optical characterization of ZnO pore-like structures surrounded by craters via pulsed laser deposition. Silicon 2017, 5, 1-6. [CrossRef]

45. Hartanto, A.B.; Ning, X.; Nakata, Y.; Okada, T. Growth mechanism of ZnO nanorods from nanoparticles formed in a laser ablation plume. Appl. Phys. A 2004, 78, 299-301. [CrossRef]

46. Sun, Y.W.; Gospodyn, J.; Kursa, P.; Sit, J.; DeCorby, R.G.; Tsui, Y.Y. Dense and porous ZnO thin films produced by pulsed laser deposition. Appl. Surf. Sci. 2005, 248, 392-396. [CrossRef]

47. Vinodkumar, R.; Navas, I.; Porsezian, K.; Ganesan, V.; Unnikrishnan, N.V.; Pillai, V.P.M. Structural, spectroscopic and electrical studies of nanostructured porous $\mathrm{ZnO}$ thin films prepared by pulsed laser deposition. Spectrochim. Acta A 2014, 118, 724-732. [CrossRef] [PubMed]

48. Ghosh, P.; Sharma, A.K. Pulsed laser deposition and characterization of ZnO nanopores. Appl. Phys. A 2016, 122, 357. [CrossRef]

49. Sun, Y.W.; Tsui, Y.Y. Production of porous nanostructured zinc oxide thin films by pulsed laser deposition. Opt. Mater. 2007, 29, 1111-1114. [CrossRef]

50. Wolcott, A.; Smith, W.A.; Kuykendall, T.R.; Zhao, Y.P.; Zhang, J.Z. Photoelectrochemical study of nanostructured $\mathrm{ZnO}$ thin films for hydrogen generation from water splitting. Adv. Funct. Mater. 2009, 19, 1849-1856. [CrossRef]

51. Labis, J.P.; Hezam, M.; Al-Anazi, A.; Al-Brithen, H.; Ansari, A.A.; El-Toni, A.M.; Enriquez, R.; Jacopin, G.; Al-Hoshan, M. Pulsed laser deposition growth of 3D $\mathrm{ZnO}$ nanowall network in nest-like structures by two-step approach. Sol. Energy Mater. Sol. Cells 2015, 143, 539-545. [CrossRef]

52. El Zein, B.; Boulfrad, S.; Jabbour, G.E.; Dogheche, E. Parametric study of self-forming ZnO nanowall network with honeycomb structure by pulsed laser deposition. Appl. Surf. Sci. 2014, 292, 598-607. [CrossRef]

53. Han, B.S.; Caliskan, S.; Sohn, W.; Kim, M.; Lee, J.K.; Jang, H.W. Room temperature deposition of crystalline nanoporous $\mathrm{ZnO}$ nanostructures for direct use as flexible DSSC photoanode. Nanoscale Res. Lett. 2016, 11, 221. [CrossRef] [PubMed]

54. Achkar, A.; Jedrzejowski, P.; Pignolet, A.; Sarkissian, A. Porous and dense ZnO films produced by femtosecond and picosecond pulsed laser deposition. J. Optoelectron. Adv. Mater. 2010, 12, 646-649.

55. Dhamodharan, P.; Manoharan, C.; Dhanapandian, S.; Venkatachalam, P. Dye-sensitized solar cell using sprayed ZnO nanocrystalline thin films on ITO as photoanode. Spectrochim. Acta A 2015, 136, 1671-1678. [CrossRef] [PubMed]

56. Studenikin, S.A.; Golego, N.; Cocivera, M. Fabrication of green and orange photoluminescent, undoped ZnO films using spray pyrolysis. J. Appl. Phys. 1998, 84, 2287-2294. [CrossRef]

57. Dobrozhan, O.; Kurbatov, D.; Opanasyuk, A.; Cheong, H.; Cabot, A. Influence of substrate temperature on the structural and optical properties of crystalline $\mathrm{ZnO}$ films obtained by pulsed spray pyrolysis. Surf. Interface Anal. 2015, 47, 601-606. [CrossRef]

58. Zahedi, F.; Dariani, R.S.; Rozati, S.M. Structural, optical and electrical properties of ZnO thin films prepared by spray pyrolysis: Effect of precursor concentration. Bull. Mater. Sci. 2014, 37, 433-439. [CrossRef]

59. Benramache, S.; Rahal, A.; Benhaoua, B. The effects of solvent nature on spray-deposited $\mathrm{ZnO}$ thin film prepared from $\mathrm{Zn}\left(\mathrm{CH}_{3} \mathrm{COO}\right)_{2}, 2 \mathrm{H}_{2} \mathrm{O}$. Optik 2014, 125, 663-666. [CrossRef]

60. Mani, G.K.; Rayappan, J.B.B. Impact of annealing duration on spray pyrolysis deposited nanostructured zinc oxide thin films. Superlattice Microstruct. 2014, 67, 82-87. [CrossRef]

61. Shaban, Z.; Ara, M.H.M.; Falahatdoost, S.; Ghazyani, N. Optimization of ZnO thin film through spray pyrolysis technique and its application as a blocking layer to improving dye sensitized solar cell efficiency. Curr. Appl. Phys. 2016, 16, 131-134. [CrossRef] 
62. Mani, G.K.; Rayappan, J.B.B. Novel and facile synthesis of randomly interconnected ZnO nanoplatelets using spray pyrolysis and their room temperature sensing characteristics. Sens. Actuators B Chem. 2014, 198, 125-133. [CrossRef]

63. Mani, G.K.; Rayappan, J.B.B. A highly selective room temperature ammonia sensor using spray deposited zinc oxide thin film. Sens. Actuators B Chem. 2013, 183, 459-466. [CrossRef]

64. Mariappan, R.; Ponnuswamy, V.; Suresh, P.; Ashok, N.; Jayamurugan, P.; Bose, A.C. Influence of film thickness on the properties of sprayed $\mathrm{ZnO}$ thin films for gas sensor applications. Superlattice Microstruct. 2014, 71, 238-249. [CrossRef]

65. Shewale, P.S.; Agawane, G.L.; Shin, S.W.; Moholkar, A.V.; Lee, J.Y.; Kim, J.H.; Uplane, M.D. Thickness dependent $\mathrm{H}_{2} \mathrm{~S}$ sensing properties of nanocrystalline $\mathrm{ZnO}$ thin films derived by advanced spray pyrolysis. Sens. Actuators B Chem. 2013, 177, 695-702. [CrossRef]

66. Tarwal, N.L.; Rajgure, A.V.; Inamdar, A.I.; Devan, R.S.; Kim, I.Y.; Suryavanshi, S.S.; Ma, Y.R.; Kim, J.H.; Patil, P.S. Growth of multifunctional $\mathrm{ZnO}$ thin films by spray pyrolysis technique. Sens. Actuators A Phys. 2013, 199, 67-73. [CrossRef]

67. Ammaih, Y.; Lfakir, A.; Hartiti, B.; Ridah, A.; Thevenin, P.; Siadat, M. Structural, optical and electrical properties of ZnO:Al thin films for optoelectronic applications. Opt. Quant. Electron. 2014, 46, 229-234. [CrossRef]

68. Mahadik, M.A.; Hunge, Y.M.; Shinde, S.S.; Rajpure, K.Y.; Bhosale, C.H. Semiconducting properties of aluminum-doped $\mathrm{ZnO}$ thin films grown by spray pyrolysis technique. J. Semicond. 2015, 36, 033002. [CrossRef]

69. Allah, F.K.; Abe, S.Y.; Nunez, C.M.; Khelil, A.; Cattin, L.; Morsli, M.; Bernede, J.C.; Bougrine, A.; del Valle, M.A.; Diaz, F.R. Characterisation of porous doped $\mathrm{ZnO}$ thin films deposited by spray pyrolysis technique. Appl. Surf. Sci. 2007, 253, 9241-9247. [CrossRef]

70. Hameed, M.S.; Princice, J.J.; Babu, N.R.; Arunachalam, A. Effect of silver doping on optical properties of nanoflower $\mathrm{ZnO}$ thin films prepared by spray pyrolysis technique. J. Mater. Sci. Mater. Electron. 2017, 28, 8675-8683. [CrossRef]

71. Mariappan, R.; Ponnuswamy, V.; Suresh, R.; Suresh, P.; Bose, A.C.; Ragavendar, M. Role of substrate temperature on the properties of Na-doped $\mathrm{ZnO}$ thin film nanorods and performance of ammonia gas sensors using nebulizer spray pyrolysis technique. J. Alloy Comp. 2014, 582, 387-391. [CrossRef]

72. Kurtaran, S.; Aldag, S.; Ofofoglu, G.; Akyuz, I.; Atay, F. Transparent conductive ZnO thin films grown by chemical spray pyrolysis: The effect of Mg. J. Mater. Sci. Mater. Electron. 2016, 27, 8478-8485. [CrossRef]

73. Dhasmana, H.; Shital, S.; Dutta, V. ZnO nanostructure thin films by continuous spray pyrolysis using doped precursor for Si solar cell application. J. Mater. Sci. Mater. Electron. 2014, 25, 4095-4102. [CrossRef]

74. Shewale, P.S.; Yu, Y.S. $\mathrm{H}_{2} \mathrm{~S}$ gas sensing properties of undoped and Ti doped $\mathrm{ZnO}$ thin films deposited by chemical spray pyrolysis. J. Alloy Comp. 2016, 684, 428-437. [CrossRef]

75. Mani, G.K.; Rayappan, J.B.B. Facile synthesis of $\mathrm{ZnO}$ nanostructures by spray pyrolysis technique and its application as highly selective $\mathrm{H}_{2} \mathrm{~S}$ sensor. Mater. Lett. 2015, 158, 373-376. [CrossRef]

76. Shewale, P.S.; Patil, V.B.; Shin, S.W.; Kim, J.H.; Uplane, M.D. $\mathrm{H}_{2} \mathrm{~S}$ gas sensing properties of nanocrystalline $\mathrm{Cu}$-doped $\mathrm{ZnO}$ thin films prepared by advanced spray pyrolysis. Sens. Actuators B Chem. 2013, 186, 226-234. [CrossRef]

77. Mani, G.K.; Rayappan, J.B.B. Selective detection of ammonia using spray pyrolysis deposited pure and nickel doped ZnO thin films. Appl. Surf. Sci. 2014, 311, 405-412. [CrossRef]

78. Muniyandi, I.; Mani, G.K.; Shankar, P.; Rayappan, J.B.B. Effect of nickel doping on structural, optical, electrical and ethanol sensing properties of spray deposited nanostructured $\mathrm{ZnO}$ thin films. Ceram. Int. 2014, 40, 7993-8001. [CrossRef]

79. Zhang, X.M.; Dong, Z.J.; Liu, S.; Yan, S.; Dong, Y.H.; Wei, F. Maize straw-templated hierarchical porous ZnO:Ni with enhanced acetone gas sensing properties. Sens. Actuators B Chem. 2017, 243, 1224-1230. [CrossRef]

80. El khalidi, Z.; Comini, E.; Hartiti, B.; Moumen, A.; Munasinghe Arachchige, H.M.M.; Fadili, S.; Thevenin, P.; Kamal, A. Effect of vanadium doping on $\mathrm{ZnO}$ sensing properties synthesized by spray pyrolysis. Mater. Des. 2018, 139, 56-64. [CrossRef]

81. Kulandaisamy, A.J.; Reddy, J.R.; Srinivasan, P.; Babu, K.J.; Mani, G.K.; Shankar, P.; Rayappan, J.B.B. Room temperature ammonia sensing properties of $\mathrm{ZnO}$ thin films grown by spray pyrolysis: Effect of $\mathrm{Mg}$ doping. J. Alloy Comp. 2016, 688, 422-429. [CrossRef] 
82. Duta, M.; Perniu, D.; Duta, A. Photocatalytic zinc oxide thin films obtained by surfactant assisted spray pyrolysis deposition. Appl. Surf. Sci. 2014, 306, 80-88. [CrossRef]

83. Ravichandran, K.; Mohan, R.; Sakthivel, B.; Varadharajaperumal, S.; Devendran, P.; Alagesan, T.; Pandian, K. Enhancing the photocatalytic efficiency of sprayed $\mathrm{ZnO}$ thin films through double doping (Sn plus F) and annealing under different ambiences. Appl. Surf. Sci. 2014, 321, 310-317. [CrossRef]

84. Dhamodharan, P.; Manoharan, C.; Dhanapandian, S.; Bououdina, M.; Ramalingam, S. Preparation and characterization of spray deposited $\mathrm{Sn}$-doped $\mathrm{ZnO}$ thin films onto ITO subtracts as photoanode in dye sensitized solar cell. J. Mater. Sci. Mater. Electron. 2015, 26, 4830-4839. [CrossRef]

85. Manoharan, C.; Pavithra, G.; Dhanapandian, S.; Dhamodharan, P. Effect of in doping on the properties and antibacterial activity of ZnO films prepared by spray pyrolysis. Spectrochim. Acta A 2015, 149, 793-799. [CrossRef] [PubMed]

86. Vasanthi, M.; Ravichandran, K.; Begum, N.J.; Muruganantham, G.; Snega, S.; Panneerselvam, A.; Kavitha, P. Influence of Sn doping level on antibacterial activity and certain physical properties of $\mathrm{ZnO}$ films deposited using a simplified spray pyrolysis technique. Superlattice Microstruct. 2013, 55, 180-190. [CrossRef]

87. Michaelis, E.; Wohrle, D.; Rathousky, J.; Wark, M. Electrodeposition of porous zinc oxide electrodes in the presence of sodium laurylsulfate. Thin Solid Films 2006, 497, 163-169. [CrossRef]

88. Kim, Y.K.; Hwang, S.H.; Kim, S.; Park, H.; Lim, S.K. ZnO nanostructure electrodeposited on flexible conductive fabric: A flexible photo-sensor. Sens. Actuators B Chem. 2017, 240, 1106-1113. [CrossRef]

89. Lv, J.G.; Wang, W.H.; Zhao, M.; Zhu, W.L.; Cheng, Y.B.; He, G.; Zhang, M.; Chen, X.S.; Sun, Z.Q. Enhanced visible light response of $\mathrm{ZnO}$ porous thin film by post-annealing treatment. J. Mater. Sci. Mater. Electron. 2017, 28, 4051-4057. [CrossRef]

90. Reemts, J.; Kittel, A. Persistent photoconductivity in highly porous ZnO films. J. Appl. Phys. 2007, 101, 013709. [CrossRef]

91. Chen, Z.G.; Tang, Y.W.; Zhang, L.S.; Luo, L.J. Electrodeposited nanoporous ZnO films exhibiting enhanced performance in dye-sensitized solar cells. Electrochim. Acta 2006, 51, 5870-5875. [CrossRef]

92. Venditti, L.; Barbero, N.; Russo, M.V.; Di Carlo, A.; Decker, F.; Fratoddi, I.; Barolo, C.; Dini, D. Electrodeposited $\mathrm{ZnO}$ with squaraine sentisizers as photoactive anode of DSCs. Mater. Res. Express 2014, 1, 015040. [CrossRef]

93. Dunkel, C.; Wark, M.; Oekermann, T.; Ostermann, R.; Smarsly, B.M. Electrodeposition of zinc oxide on transparent conducting metal oxide nanofibers and its performance in dye sensitized solar cells. Electrochim. Acta 2013, 90, 375-381. [CrossRef]

94. Pauporte, T.; Rathousky, J. Electrodeposited mesoporous $\mathrm{ZnO}$ thin films as efficient photocatalysts for the degradation of dye pollutants. J. Phys. Chem. C 2007, 111, 7639-7644. [CrossRef]

95. Dikici, T. Temperature-dependent growth of $\mathrm{ZnO}$ structures by thermal oxidation of $\mathrm{Zn}$ coatings electrodeposited on steel substrates and their photocatalytic activities. Ceram. Int. 2017, 43, 8289-8293. [CrossRef]

96. Wanotayan, T.; Panpranot, J.; Qin, J.; Boonyongmaneerat, Y. Microstructures and photocatalytic properties of $\mathrm{ZnO}$ films fabricated by $\mathrm{Zn}$ electrodeposition and heat treatment. Mater. Sci. Semicond. Proc. 2018, 74, 232-237. [CrossRef]

97. Lu, H.; Zhang, M.; Guo, M. Controllable electrodeposition of ZnO nanorod arrays on flexible stainless steel mesh substrate for photocatalytic degradation of Rhodamine B. Appl. Surf. Sci. 2014, 317, 672-681. [CrossRef]

98. Yang, J.; Wang, Y.Q.; Kong, J.H.; Jia, H.X.; Wang, Z.S. Synthesis of ZnO nanosheets via electrodeposition method and their optical properties, growth mechanism. Opt. Mater. 2015, 46, 179-185. [CrossRef]

99. Li, H.; Yu, S.R.; Han, X.X. Preparation of a biomimetic superhydrophobic ZnO coating on an X90 pipeline steel surface. New J. Chem. 2015, 39, 4860-4868.

100. Li, M.; Zhai, J.; Liu, H.; Song, Y.L.; Jiang, L.; Zhu, D.B. Electrochemical deposition of conductive superhydrophobic zinc oxide thin films. J. Phys. Chem. B 2003, 107, 9954-9957. [CrossRef]

101. Pal, B.; Sharon, M. Enhanced photocatalytic activity of highly porous $\mathrm{ZnO}$ thin films prepared by sol-gel process. Mater. Chem. Phys. 2002, 76, 82-87. [CrossRef]

102. Wang, C.F.; Tzeng, F.S.; Chen, H.G.; Chang, C.J. Ultraviolet-durable superhydrophobic zinc oxide-coated mesh films for surface and underwater-oil capture and transportation. Langmuir 2012, 28, 10015-10019. [CrossRef] [PubMed]

103. Zhang, J.; Wang, S.R.; Xu, M.J.; Wang, Y.; Zhu, B.L.; Zhang, S.M.; Huang, W.P.; Wu, S.H. Hierarchically porous $\mathrm{ZnO}$ architectures for gas sensor application. Cryst. Growth Des. 2009, 9, 3532-3537. [CrossRef] 
104. Chatterjee, A.P.; Mitra, P.; Mukhopadhyay, A.K. Chemically deposited zinc oxide thin film gas sensor. J. Mater. Sci. 1999, 34, 4225-4231. [CrossRef]

105. Hosono, E.; Fujihara, S.; Kimura, T.; Imai, H. Growth of layered basic zinc acetate in methanolic solutions and its pyrolytic transformation into porous zinc oxide films. J. Colloid Interface Sci. 2004, 272, 391-398. [CrossRef] [PubMed]

106. Wang, H.H.; Xie, C.S. Controlled fabrication of nanostructured $\mathrm{ZnO}$ particles and porous thin films via a modified chemical bath deposition method. J. Cryst. Growth 2006, 291, 187-195. [CrossRef]

107. Wang, H.H.; Dong, S.J.; Chang, Y.; Zhou, X.P.; Hu, X.B. Microstructures and photocatalytic properties of porous $\mathrm{ZnO}$ films synthesized by chemical bath deposition method. Appl. Surf. Sci. 2012, 258, 4288-4293. [CrossRef]

108. Ottone, C.; Bejtka, K.; Chiodoni, A.; Farias, V.; Roppolo, I.; Canavese, G.; Stassi, S.; Cauda, V. Comprehensive study of the templating effect on the $\mathrm{ZnO}$ nanostructure formation within porous hard membranes. New J. Chem. 2014, 38, 2058-2065. [CrossRef]

109. Ottone, C.; Rivera, V.F.; Fontana, M.; Bejtka, K.; Onida, B.; Cauda, V. Ultralong and mesoporous ZnO and gamma- $\mathrm{Al}_{2} \mathrm{O}_{3}$ oriented nanowires obtained by template-assisted hydrothermal approach. J. Mater. Sci. Technol. 2014, 30, 1167-1173. [CrossRef]

110. Ryu, H.W.; Park, B.S.; Akbar, S.A.; Lee, W.S.; Hong, K.J.; Seo, Y.J.; Shin, D.C.; Park, J.S.; Choi, G.P. ZnO sol-gel derived porous film for CO gas sensing. Sens. Actuators B Chem. 2003, 96, 717-722. [CrossRef]

111. Leone, F.; Gignone, A.; Ronchetti, S.; Cavalli, R.; Manna, L.; Banchero, M.; Onida, B. A green organicsolvent-free route to prepare nanostructured zinc oxide carriers of clotrimazole for pharmaceutical applications. J. Clean. Prod. 2018, 172, 1433-1439. [CrossRef]

112. Liu, Z.F.; Jin, Z.G.; Li, W.; Qiu, J.J.; Zhao, J.; Liu, X.X. Synthesis of PS colloidal crystal templates and ordered $\mathrm{ZnO}$ porous thin films by dip-drawing method. Appl. Surf. Sci. 2006, 252, 5002-5009. [CrossRef]

113. Yan, H.W.; Yang, Y.L.; Fu, Z.P.; Yang, B.F.; Xia, L.S.; Fu, S.Q.; Li, F.Q. Fabrication of 2D and 3D ordered porous $\mathrm{ZnO}$ films using 3D opal templates by electrodeposition. Electrochem. Commun. 2005, 7, 1117-1121. [CrossRef]

114. Liu, Z.F.; Jin, Z.G.; Li, W.; Qiu, J.J. Preparation of ZnO porous thin films by sol-gel method using PEG template. Mater. Lett. 2005, 59, 3620-3625. [CrossRef]

115. Liu, Z.F.; Jin, Z.G.; Qiu, J.J.; Liu, X.X.; Wu, W.B.; Li, W. Preparation and characteristics of ordered porous $\mathrm{ZnO}$ films by a electrodeposition method using PS array templates. Semicond. Sci. Technol. 2006, 21, 60-66. [CrossRef]

116. Liu, Z.F.; Jin, Z.G.; Li, W.; Liu, X.X. Ordered porous ZnO thin films formed by dip-coating method using PS templates. J. Sol-Gel Sci. Technol. 2006, 40, 25-30. [CrossRef]

117. Cao, B.Q.; Cai, W.P.; Sun, F.Q.; Li, Y.; Lei, Y.; Zhang, L.D. Fabrication of large-scale zinc oxide ordered pore arrays with controllable morphology. Chem. Commun. 2004, 1604-1605. [CrossRef] [PubMed]

118. Eltayeb, A.; Daniels, S.; McGlynn, E. Enhanced optical properties of $\mathrm{ZnO}$ and $\mathrm{CeO}_{2}$-coated $\mathrm{ZnO}$ nanostructures achieved via spherical nanoshells growth on a polystyrene template. Sci. Rep. 2017, 7, 3737. [CrossRef] [PubMed]

119. Xiong, Y.Y.; Kang, F.; Ke, Z.; Zhuo, S.Y.; Liang, C.F.; Zhang, Z.X. Fabrication and characterization of three-dimensional core-shell structure $\mathrm{ZnO}$ photonic crystals by magnetron sputtering based on opal template. J. Cryst. Growth 2010, 312, 2484-2488.

120. Lin, X.; Chen, M. Fabrication and photo-detecting performance of 2D ZnO inverse opal films. Appl. Sci. 2016, 6, 259. [CrossRef]

121. Wang, Z.H.; Tian, Z.W.; Han, D.M.; Gu, F.B. Highly sensitive and selective ethanol sensor fabricated with In-doped 3DOM ZnO. ACS Appl. Mater. Inter. 2016, 8, 5466-5474. [CrossRef] [PubMed]

122. Su, X.S.; Duan, G.T.; Xu, Z.K.; Zhou, F.; Cai, W.P. Structure and thickness-dependent gas sensing responses to $\mathrm{NO}_{2}$ under $\mathrm{UV}$ irradiation for the multilayered $\mathrm{ZnO}$ micro/nanostructured porous thin films. J. Colloid Interface Sci. 2017, 503, 150-158. [CrossRef] [PubMed]

123. Cheng, K.; Li, Q.Q.; Meng, J.; Han, X.; Wu, Y.Q.; Wang, S.J.; Qian, L.; Du, Z.L. Interface engineering for efficient charge collection in $\mathrm{Cu}_{2} \mathrm{O} / \mathrm{ZnO}$ heterojunction solar cells with ordered $\mathrm{ZnO}$ cavity-like nanopatterns. Sol. Energy Mater. Sol. Cells 2013, 116, 120-125. [CrossRef]

124. Kim, E.; Vaynzof, Y.; Sepe, A.; Guldin, S.; Scherer, M.; Cunha, P.; Roth, S.V.; Steiner, U. Gyroid-structured 3D $\mathrm{ZnO}$ networks made by atomic layer deposition. Adv. Funct. Mater. 2014, 24, 863-872. [CrossRef] 
125. Yong, J.L.; Chen, F.; Yang, Q.; Fang, Y.; Huo, J.L.; Hou, X. Femtosecond laser induced hierarchical ZnO superhydrophobic surfaces with switchable wettability. Chem. Commun. 2015, 51, 9813-9816. [CrossRef] [PubMed]

126. Balela, M.D.L.; Pelicano, C.M.O.; Ty, J.D.; Yanagi, H. Formation of zinc oxide nanostructures by wet oxidation of vacuum deposited Zn thin film. Opt. Quant. Electron. 2017, 49, 3. [CrossRef]

127. Alcaire, M.; Filippin, A.N.; Macias-Montero, M.; Sanchez-Valencia, J.R.; Rojas, T.C.; Mora-Boza, A.; Lopez-Santos, C.; Espinos, J.P.; Barranco, A.; Borras, A. Highly porous ZnO thin films and 1D nanostructures by remote plasma processing of Zn-phthalocyanine. Plasma. Process. Polym. 2016, 13, 287-297. [CrossRef]

128. Wang, H.J.; Sun, Y.Y.; Cao, Y.; Yu, X.H.; Ji, X.M.; Yang, L. Porous zinc oxide films: Controlled synthesis, cytotoxicity and photocatalytic activity. Chem. Eng. J. 2011, 178, 8-14. [CrossRef]

129. Sacco, A.; Lamberti, A.; Gazia, R.; Bianco, S.; Manfredi, D.; Shahzad, N.; Cappelluti, F.; Ma, S.; Tresso, E. High efficiency dye-sensitized solar cells exploiting sponge-like $\mathrm{ZnO}$ nanostructures. Phys. Chem. Chem. Phys. 2012, 14, 16203-16208. [CrossRef] [PubMed]

(C) 2018 by the authors. Licensee MDPI, Basel, Switzerland. This article is an open access article distributed under the terms and conditions of the Creative Commons Attribution (CC BY) license (http://creativecommons.org/licenses/by/4.0/). 